\title{
Radyofrekans/Mikrodalga Elektromanyetik Radyasyonun Anksiyete ve Depresyon Üzerine Etkileri: Deneysel Hayvan Modellerine Dayalı Çalışmalara Ait Literatür Taraması
}

\author{
Anzel BAHADIR 國
}

\section{ÖZ}

Günümüzde anksiyete ve/veya depresyon dünyada en yaygın gözlenen duygusal (emosyonel) davranış bozukluklarıdır. Bu derlemede, radyofrekans/mikrodalga-elektromanyetik radyasyonun (RF/MW-EMR) deneysel hayvan modellerinde anksiyete ve depresyon bozuklukları üzerindeki etkilerinin araştırılması amaçlanmıştır. Derlemede, 2005-2019 yılları arasında yayınlanmış toplam 31 çalışma incelenmiş olup, bu çalışmalara ait uygulanan frekans aralığı, spesifik absorbsiyon oranı, güç yoğunluğu veya elektrik alan, radyasyon maruziyet kurulumu, maruziyet süresi ve bölgesi, hayvan modeli ve yaşı, ölçülen deneysel parametreler ile çalışmaların sonuçları değerlendirilmiştir. Değerlendirilen literatür verilerindeki anksiyete ve/veya depresyon üzerine RF/MW-EMR maruziyetinin etkileri incelendiğinde, EMR'nun 19 anksiyete çalışması ile bir depresyon çalışmasında pozitif etkileri, beş anksiyete çalışması ile bir depresyon çalışmasında negatif etkileri belirlenirken, dokuz anksiyete çalışması ile üç depresyon çalışmasında EMR maruziyetinin anlamlı derecede bir etkisi gözlenmemiştir. Ayrıca değerlendirilen bu çalışmaların sekizinde, deneysel hayvan modeli özellikleri, radyasyon maruziyet koşulları, davranış testleri ve nörogelişimsel süreçlere bağlı olarak değişken sonuçlar saptanmıştır. Sonuç olarak derlemede, RF/MW-EMR maruziyetinin anksiyete ve/veya depresyon bozukluklarının oluşumunu etkileyebileceği gözlenmiş olup, literatürdeki mevcut veriler 1şı̆̆ında, nöral ve moleküler mekanizmalara dayalı ileri araştırmaların yararlı olabileceği düşünülmektedir.

Anahtar Kelimeler: Radyofrekans/mikrodalga-elektromanyetik radyasyon; anksiyete; depresyon; deneysel hayvan modelleri.

\section{Effects of Radiofrequency/Microwave Electromagnetic Radiation on Anxiety and Depression: Literature Review Related to Studies Based on Experimental Animal Models}

\begin{abstract}
Anxiety and/or depression are the most common emotional behavior disorders in the world. This review aimed to investigate the effects of radiofrequency/microwave-electromagnetic radiation (RF/MW-EMR) on anxiety and depression disorders in the experimental animal models. In the review, a total of 31 studies published between 20052019 were examined and frequency range, specific absorption rate, power density or electric field, setup, time and region of radiation exposure, animal model and age, measured experimental parameters and results related to these studies were evaluated. Regarding the effects of RF/MW-EMR exposure on anxiety and/or depression in the literature, the EMR effects were found positive in 19 studies on anxiety and one study on depression and negative in five studies on anxiety and one study on depression, while no significant effect of EMR exposure was observed in nine studies on anxiety and three studies on depression. Additionally, in eight studies, various results were found depending on experimental animal model characteristics, radiation exposure conditions, behavior tests, and neurodevelopmental processes. Consequently, the current findings show that RF/MW-EMR exposure may affect the occurrence of anxiety and/or depression disorders so suggest that further research based on neural and molecular mechanisms may be useful in the light of available data in the literature.
\end{abstract}

Keywords: Radiofrequency/microwave-electromagnetic radiation; anxiety; depression; experimental animal models. 


\section{GIRIŞ}

Günümüzde kablosuz bağlantı (WiFi: wireless fidelity) ağ teknolojilerinin yaygın kullanımına bağlı olarak, elektromanyetik radyasyon (EMR) maruziyetindeki sürekli artış sonucu oluşacak insan sağlığı üzerindeki etkilerinin, hem sosyal hem de bilimsel çevrede daha çok araştırılarak, tüm dikkatleri üzerinde toplamaya başladığ gözlenmektedir (1). İnternet kullanımı modern yaşamın vazgeçilmez bir parçası haline geldiğinden, evde, işyerlerinde, ortak toplumsal alanlarda ve okullarda, akıllı telefonlar, WiFi, dizüstü ve masa üstü bilgisayarlar ile bağlı ofis cihazları gibi birçok radyasyon kaynaklarından elektromanyetik alanlara (EMA) maruz kalınmaktadır (2). Radyofrekans (RF: radiofrequency) dalgalar ve mikrodalgalar (MW: microwaves), EM spektrumun elektromanyetik iyonizasyona neden olmak için yeterli enerjiye sahip olmayan iyonlaştırıcı olmayan radyasyonlar bölgesinde yer almaktadırlar. Radyofrekans elektromanyetik radyasyonlar (RF-EMR), EM spektrumdaki $3 \mathrm{kHz}$ ile $300 \mathrm{GHz}$ ferkans aralığında geniş bir bölgeyi içermekte ve bu radyasyonlar cep telefonları, WiFi teknolojileri gibi telekomünikasyon sistemleri, askeri radar sistemleri, uydu iletişimlerinden yayınlanmaktadırlar. RF-EMR, farklı biyolojik organizmalar ile etkileşerek, termal (1sısal) ve termal olmayan (isisal olmayan) yollardan fizyolojik sistemleri etkilemesine rağmen, henüz etki mekanizmaları tam olarak açıklığa kavuşamamıştır $(3,4)$. Mikrodalga elektromanyetik radyasyonlar (MW-EMR), frekans ve güçlerine bağlı olarak vücudumuzu etkileyen RFEMR'ların bir türü olup, bu radyasyonlar $300 \mathrm{MHz}$ ile $300 \mathrm{GHz}$ olarak ifade edilen yüksek frekans aralığına sahip bölgelerdir. Bu frekanslar, kısa mesafeli kablosuz bağlantı ve cep telefonlarındaki Bluetooth, bilgisayarlar için kablosuz yazıc1, klavye ve fare gibi kablo yer değiştirici sistemlerde ve mikrodalga firınlarda kullanılmaktadır. Dolayısıyla, günlük yaşamda kullanılan modern cep telefonları, diz üstü bilgisayarlar, WiFi teknolojileri ve mikrodalga firınlar, yüksek frekanslı $(2.45 \mathrm{GHz})$ mikrodalga radyasyonunda çalışmaktadırlar. MW-EMR'lar, termal olmayan (1sisal olmayan) yollardan canlı hücrelerin informasyon taşıyan biyolojik makromolekülleri olan lipit, protein ve nükleik asitler ile etkileşmektedirler (5-7).

RF/MW-EMR'nun sağlı üzerinde etki mekanizmalarından biri olan termal (1sisal) etkisi sonucu, doku sıcaklığında bölgesel artışa bağlı olarak hücresel fonksiyonlarda bozulmalar meydana gelmektedir. Bölgesel 1sınma derecesi, radyasyon yayan cihazlardan yayınlanan elektromanyetik dalgaların güç yoğunluğu ve spesifik absorbiyon oranına (SAR: specific absorbsition rate) bağlıdır. Termal olmayan (1sısal olmayan) etki ise, başlica radyasyon ve vücuttaki hücreler arasındaki etkileşime bağlı olarak hücreler ve dokularda üretilen stresten kaynaklanmaktadır $(4,6)$. Güç yoğunluğu, birim alan başına güç olarak tanımlanmakta ve metrekare başına watt birimi $\left(\mathrm{W} / \mathrm{m}^{2}\right)$ ile belirtilmektedir. SAR parametresi ise, RF-EMR'a maruz kalındığında, insan vücudu tarafından soğrulan enerji hızının bir ölçüsüdür. $\mathrm{Bu}$ parametre, birim doku kütlesi başına soğrulan güç olarak tanımlanmakta ve kilogram başına watt birimi (W/kg) ile ifade edilmektedir. SAR parametresi, genellikle ya tüm vücut ya da vücudun küçük bir hacmi (tipik olarak 1 gr veya 10 gr doku) üzerindeki ortalama değeri göstermektedir. $\mathrm{Bu}$ değer, belirtilen hacim veya kütle üzerinde incelenen vücut kısmında ölçülen maksimum seviyeyi vermektedir. Cep telefonları için SAR değerleri, daima mümkün olan maksimum iletim gücünü ifade eder. SAR, farklı ülkelerdeki radyasyon sınırlarını düzenleyici kurumlar tarafından belirlenen güvenlik yönergeleri doğrultusunda cep telefonlarının RF-EMR'ye maruz kalma özelliklerini ölçmede kullanılan güvenilir bir ölçektir. Cep telefonlarının toplumsal maruziyet için SAR limit değeri, "Fedaral İletişimler Komisyonu (FCC: Federal Communications Commission)"' tarafından kilogram başına 1,6 watt $(1,6$ $\mathrm{W} / \mathrm{kg}$ ) olarak belirlenmiş olmasına rağmen, bu değer her bir ülkenin radyasyon sınırlarını düzenleyici kurumları tarafından önemli ölçüde farklılık gösterebilmektedir $(3,8)$.

Anksiyete ve depresyon dünyada en önde gelen mental sağlık sorunlarından biridir. Anksiyete, korku, kayg1/endişe, kaçınma, geri çekilme ve diğer anksiyete ile ilişkili semptomlar gibi genel semptomlar gösteren fiziksel ve psikolojik rahatsızlıklar oluşturan, depresyon ise, yüksek düzeylerde üzüntü ve fonksiyon bozukluğu sergileyen duygusal (emosyonel) davranış bozukluklarıdır $(3,9)$. İnsan ve hayvanların duygularını ortaya koyma şekilleri benzerlik gösterdiğinden ve insanlar üzerinde stres faktörlerinin çalışılması etik ve benzeri nedenler dolayısıyla gerçekleştirilemediğinden, davranışsal bozuklukların araştırılmasında farklı deneysel hayvan modelleri ve testlerinden yararlanılmaktadır $(10,11)$.

Literatürde, farklı hayvan modelleri üzerinde EMR'nun anksiyete/depresyon ilişkili davranışlar üzerine etkisine dayalı birçok çalışma bulunmasına rağmen, bu çalışmanın sonuçları farklı deneysel koşullardan (maruziyet sistemleri, frekans, güç yoğunluğu ve SAR değerleri, maruziyet süresi, maruziyet bölgesi (baş veya vücut) vb) ve kullanılan hayvan modellerinin özellikleri (cinsi, yaşı, cinsiyeti vb) yüzünden tartışmalı veriler sunmaktadır (1240). Bu derlemede, çoğunlukla cep telefonu teknolojisi ile ilişkili olan RF/MW-EMR maruziyetinin deneysel hayvanların anksiyete ve/veya depresyon davranış bozukluklarını etkileyip etkilemeyeceği konusunda genel bir bakış açısı oluşturmak amacıyla, bu alanda gerçekleştirilmiş kapsamlı literatür araştırma sonuçlarının irdelenmesi amaçlandı. $\mathrm{Bu}$ amaç doğrultusunda derlemede, 2005-2019 yılları arasında yayınlanmış ve RF/MW-EMR'nun anksiyete/anksiyete ilişkili davranışlar üzerindeki etkilerini içeren 27 çalışma ile hem anksiyete/anksiyete ilişkili davranışlar hem de depresyon/depresyon ilişkili davranışlar üzerindeki etkileri içeren dört çalışma olmak üzere toplam 31 çalışma incelendi. Bu çalışmalara, Pubmed/MEDLINE, Web of Science, ScienceDirect, EBSCOhost, EMBASE ve Scopus veri tabanlarında aşağıdaki anahtar kelimeler taranarak ulaşılmıştır: radyo dalgaları (radio waves), mikrodalgalar (microwaves), elektromanyetik alan (electromagnetic field), elektromanyetik radyasyon (electromagnetic radiation), radyofrekanselektromanyetik radyasyon (radiofrequencyelectromagnetic radiation), mikrodalga-elektromanyetik radyasyon (microwave- electromagnetic radiation), yüksek frekanslı elektromanyetik alan (high frequency 
electromagnetic field), cep telefonu (cellular phone or telephone or mobile phone), WiFi (wireless fidelity), GSM (Global System for Mobile Communication), anksiyete (anxiety), depresyon (depression), anksiyete ilişkili/benzeri davranış (anxiety related/like behavior or behaviour), depresyon ilişkili/benzeri davranış (depression related/like behavior or behaviour), sıçan (rat), fare (mouse), deneysel hayvan modelleri (experimental animal models). Derlemede, bu çalışmalara ait $840 \mathrm{MHz}$ frekans şiddeti ve üzerindeki RF/MW-EMR frekans aralığı, SAR, güç yoğunluğu veya elektrik alan, radyasyon maruziyet kurulum sistemi, maruziyet süresi ve bölgesi, hayvan modeli ve yaşı, incelenen deneysel parametreler ile çalışmaların sonuçları değerlendirilmiştir. Derlemede incelenen anksiyete veya anksiyete benzeri davranış üzerine RF/MW-EMR maruziyetinin etkileri ile ilgili çalışmalar değerlendirildiğinde, 19 çalışmada pozitif etki $(6,12,13$, 17, 18, 20, 22, 24, 25, 27-29, 32-34, 36, 37, 39, 40), beş çalışmada negatif etki $(16,22,23,30,32)$ gözlenmiştir ve dokuz çalışmada ise herhangi bir anlamlı etki gözlenmemiştir $(7,14,15,19,21,26,31,35,38)$. Bununla birlikte depresyon veya depresyon benzeri davranış üzerine RF/MW-EMR maruziyetinin etkileri ile ilgili çalışmalar değerlendirildiğinde ise, bir çalışmada pozitif etki (37), bir çalışmada negatif etki (40) saptanmış ve üç çalışmada ise anlamlı bir etki saptanmamıştır (7, 25, 37). Değerlendirilen literatür çalışmaları içinde, araştırmada kullanılan deneysel hayvanın cinsiyetine (22, $34)$, anksiyete veya depresyon davranış testlerine $(13,16$, 17), EMA maruziyetindeki deneysel koşullar (frekans şiddeti, genlik modülasyonu, SAR değeri vb) ve/veya çevresel koşullara adaptasyon süreçlerine bağlı deney protokollerine $(23,32,37)$ ve nörogelişimsel süreçlere (30) göre bu çalışmalarda RF/MW-EMR maruziyetinin etkilerinde farklı veya değişken sonuçlar elde edilmiştir. $\mathrm{Bu}$ derleme çalışması, bilimsel araştırma ve yayın etiği kurallarına uygun olarak hazırlanmıştır.

Deneysel Hayvan Modellerinde RF/MW-EMR Maruziyetinin Anksiyete ve Depresyon Üzerine Etkilerini İçeren Literatür Çalışmaları

\section{A. $840 \mathrm{MHz}$ veya $900 \mathrm{MHz}$ EMR Maruziyetlerine Ait} Literatür Çalışmaları

Daniels ve arkadaşları (12) çalışmalarında, RF sinyal jenaratör ile uygulanan $840 \mathrm{MHz}$ frekansındaki RF-EMR maruziyetinin dişi ve erkek Sprague-Dawley sıçan yavrularında $(n=24)$, ögrenme, hafiza, emosyonel stres ve kortikosteron düzeyleri üzerindeki etkilerini, davranışsal, histolojik ve biyokimyasal testler ile incelemişlerdir. Sıçan yavruları, her bir grupta altı dişi ve altı erkek olacak şekilde, doğum sonrası (postnatal) ikinci günden (P2), 14. güne (P14) kadar günde üç saat EMR uygulanan maruziyet grubu ve EMR maruziyeti uygulanmayan kontrol grubu olarak iki gruba ayrılmıştır. Bu sıçanların uzaysal hafiza ve spesifik bir görevi öğrenebilmelerini değerlendirmek için Morris su labirenti (MWM: Morris water maze) testi uygulanmıştır. Ayrıca çalışmada açık alan (OF: open field) testi kullanılarak, lokomotor aktivite, keşifsel davranış ve süslenme (grooming) gibi parametreler ile anksiyete benzeri davranış ve duygu durum bozuklukları değerlendirilmiştir. Çalışma bulgularında, MWM ölçümlerine göre, RF-EMR maruziyeti her iki cinsiyet grubunda öğrenme ve hafiza yeteneğini önemli ölçüde etkilememiştir. Çünkü uzaysal bellek testinde ve beynin morfolojik değerlendirilmesinde, gruplar arasında anlamlı farklılıklar saptanmamış, fakat sıçanların lokomotor aktiviteleri RFEMR maruziyeti ile azalmıştır. Ayrıca OF testi sonuçlarında, RF-EMR'a maruz kalan erkek sıçanların lokomotor aktiviteleri, maruziyet uygulanmamış kontrol grubunun aktivitelerine göre anlamlı derecede azalmıştır. Gruplar arasında keşifsel davranış açısından bir farklılık gözlenmemesine rağmen, RF-EMR maruziyetine uğramış erkek sıçanlar kontrol grubuna göre, süslenme (grooming)'de daha fazla zaman harcamışlardır. Sonuç olarak çalışmada, radyasyona maruz kalan bazı sıçanlarda (özellikle erkek sıçanlarda), lokomotor aktivitede azalma, süslenme (grooming) ve donma davranışında artmalar ile RF-EMR'nin davranışsal anormallikler ve duygu durum bozuklukları gelişimine neden olduğu saptanmıştır. Dolayısıyla RF-EMR maruziyetinin davranışta anormalliklere neden olarak stres ilişkili bozuklukların oluşumunu tetikleyen çevresel bir risk faktörü olabileceği ileri sürülmüştür. Ayrıca bu çalışmada, bazal kortikosteron düzeylerinde gruplar arasında anlamlı farklılıklar bulunmazken, dişi kontrol sıçanlara göre RFEMR'a maruz kalan dişi sıçanlarda, daha yüksek kortikosteron düzeyleri belirlenmiştir $(p<0,06)$. Bu bulgular, RF-EMR maruziyetinin anormal beyin fonksiyonları yanında, anksiyete benzeri davranışa neden olduğunu ortaya koymuştur (Tablo 1).

Petitdant ve arkadaşları (13) çalışmalarında, $900 \mathrm{MHz}$ GSM RF-EMR toksisitesinin maternal immün aktivasyonunu arttırıp arttırmadığını araştırmayı ve yavru (progeny) glial homeostazı ile sensorimotor geçidinde, duygusallık, yenilik arayışı yetenekleri üzerine gestasyonel RF-EMR'nın risk eşiğini belirleyebilmeyi amaçlamışlardır. $\mathrm{Bu}$ amaçlar doğrultusunda, gebe Sprague-Dawley sıçanlara $(n=70)$, tüm gestasyonel dönem (GD) boyunca, bitişik döngü (loop) şeklindeki antenler aracılığıyla karın (abdomen) bölgelerine sınırlandırılmış olarak RF-EMR maruziyeti (fetus vücudu için SAR: 0, 0,7 veya 2,6 W/kg) ve 15,17 ve 19 GD'inde toplam üç kez intraperitoneal (ip) olarak lipopolisakkarit (LPS) veya saline enjeksiyonu ( 0 veya $80 \mu \mathrm{g} / \mathrm{kg})$ uygulanmıştır. Siçanların duygusal (emosyonel) hafiza, anksiyete ilişkili davranışları, ön uyaran aracılı inhibisyon (PPI: pre-pulse inhibition), korku koşullandırma (FC: fear conditioning) paradigması, OF ve yükseltilmiş artı labirent (EPM: elevated plus maze) testleri ile incelenir iken, interlökin (IL)-1 $\beta$ ve glial fibriler asidik protein (GFAP) düzeyleri de belirlenmiştir. Çalışma bulgularında, gestasyonel uygulamalarda (RF-EMR, LPS ve RF-EMR-LPS kombinasyonu) veya yaş ile etkileşimlerinde, EPM testinin açık kolunda harcanan zaman yüzdeleri açısından herhangi bir etki saptanmamıştır. Yaş, LPS ve RF-EMR veya kombinasyonları herhangi bir etki göstermez iken, yaşa bağl1 olarak IL-1 $\beta \quad(p<0,001)$ ve GFAP $(p=0,001)$ düzeyleri artmıştır. Korku belleği yanıtı, gestasyonel RFEMR, LPS veya etkileşimlerinden etkilenmez iken, hafiza $(p=0,009)$ ve bellek türünden $(p=0,001)$ etkilenmiştir. Ek olarak irkilmenin (startle), RF-EMR veya LPS ile değişmediği, erişkinlerde ergenlere göre daha yüksek genliğe (amplitüde) sahip olduğu belirlenmiştir $(\mathrm{p}<0,001)$. PPI yüzdeleri üzerinde RF-EMR 
veya LPS etkisinin olmadığı da gözlenmiştir. Fakat sadece yetişkin LPS grubunda, PPI testi ile irkilme genliği ve RF-EMR düzeyleri arasında anlamlı düzeyde ters bir korelasyon belirlenmiştir $(p=0,03)$. Ayrıca RFEMR, LPS, yaş veya kombinasyonlarının, merkezi lokomotor aktivite üzerine herhangi bir etkisi saptanmamıştır. Sonuç olarak maternal immün aktivasyonu, sensorimotor geçidinde SAR bağımlı bir azalmayı tetiklemiştir. Maternal RF-EMR, erişkin skorlarını etkilemediği halde, ergenlerde yeni ortamın sunumunda SAR'a bağımlı olarak OF testinde yatay aktiviteyi azaltmıştır. Kısıtlama olmadan maternal immün aktivasyondan sonra aktivite ergenlerde azalmış, erişkinlerde artmıştır. PPI, sadece gestasyonel GSM uygulaması ile etkilenmemiş, fakat immün aktive edilmiş modelde seçici olarak SAR bağımlı bir azalma göstermiştir. Ayrıca OF yanıtları, sadece kafes kontrol grubundaki anne sıçanların yavrularında gözlenmiştir, bu sonuç araştırmacılara günlük kısıtlamaya bağlı gebelik stresinin muhtemelen yavruların skorlarını etkilediğini düşündürmüştür. Dolayısıyla çalışma bulguları, maternal immün aktivasyonun, gelişimsel RF-EMR'a bağlı uzun süreli nörobiyolojik bozuklukları arttırdığı hipotezini desteklemiştir (Tablo 1).

Petitdant ve arkadaşları (14) diğer bir çalışmalarında, sıçanların ergenlik dönemleri boyunca RF-EMR maruziyetinin, astrosit reaktiviteleri, alg1 ve duygulanım (emosyonalite) durumlarını etkileyip etkilemediğini ve ergen beyinlerin nörogelişimsel inflamasyondan sonra RF-EMR maruziyetine daha duyarlı olup olmadı̆̆ını araştırmışlardır. Çalışmada, hamile dişi sıçan (n=17, GD $9 \pm 1)$ ve erkek Sprague-Dawley erkek siçan $(n=81, P 21)$ kullanılmıştır. Çalışmadaki doğum sonrası (postnatal, P) olarak ifade edilen dönemlerde yer alan P25-26'da siçanlar, rastgele olarak P32'de LPS veya yapay serebrosipinal sivi (aCSF: artificial cerebrospinal fluid) grubu, bir SAR değerine sahip (SAR: $0,1,5$ veya $6 \mathrm{~W} / \mathrm{kg}$ ) grup, kafes kontrol (cerrahi olan fakat kisitlama olmayan) ve cerrahi kontrol grup (cerrahi olmayan fakat kisitlama olan) olarak deney gruplarına ayrılmıştır. Gebelik süresince sıçanlara $80 \mathrm{mg} / \mathrm{kg}$ intraperitoneal (ip) LPS enjeksiyonu veya ergenlik boyunca 1,25 $\mu \mathrm{g} / \mathrm{saat}$

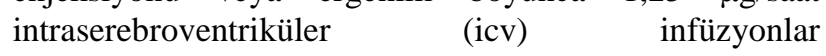
gerçekleştirilmiştir. Deney grubundaki sıçanların beyin bölgesine, P32'den P62 döneme kadar, GSM 900 MHz frekans üreten RF güç kaynağı ile haftada beş gün 45 dakikalık sürelerde RF-EMR maruziyeti (SAR: 0, 1,5 veya $6 \mathrm{~W} / \mathrm{kg}$ ) uygulanmıştır. P56 döneminden sonra sıçanların, yenilik (novelty) algısı OF testi, anksiyete benzeri davranışları EPM veya OF testleri ve duygusal (emosyonel) hafıza değerlendirmeleri FC testi ile analiz edilmiştir. Dönem P64'de, astrosit reaktiviteleri ve GFAP düzeyleri ölçülmüş, ergenlik dönemi boyunca RF-EMR maruziyetinin, sıçanların astrosit reaktivitesi, yenilik (novelty) algıs1, duygusallık düzeyleri ve GFAP seviyelerini değiştirmediği, fakat ergen sıçanların gestasyonel inflamasyondan sonra veya nöroinflamasyon süresi boyunca RF-EMR maruziyetine daha duyarlı oldukları saptanmıştır. Sham- kontrol maruziyet grubu ile karşılaştırıldığında, sağlıklı ve yüksek SAR değerine sahip RF'a maruz kalmış sıçanlarda, herhangi bir nörobiyolojik bozulma gözlenmemiştir. Amigdaladaki GFAP seviyesi değişikliğinin olmaması, sağlıklı duyusal süreçlerle (anksiyete ilişkili davranışlar, uzun süreli ve korku ipucuna dayalı hafizalar) tutarlı bulunmuştur. Ayrica, RF-EMR maruziyetinin anksiyete benzeri davranışlar üzerinde herhangi bir etkisi de belirlenmemiştir. Çalışma bulgularına göre, ergen sıçan beyinlerinde RF-EMR maruziyeti ile LPS enjeksiyonu arasında sinerjik bir etki olmadığı ileri sürülmüştür. Çünkü LPS ile indüklenen GFAP seviyelerindeki artış, RF-EMR maruziyeti ile daha da artmamıştır. Dolayısıyla çalışma bulguları, nörogelişimsel inflamasyondan sonra bile ergen sıçanların RF-EMR'a spesifik serebral duyarlılık göstereceği hipotezini desteklememiştir (Tablo 1).

Barthélémy ve arkadaşları (15) çalışmalarında, nöronal hasar ve fonksiyonel bozuklukların, yüksek SAR kaynaklı astrogliozis ile ilişkili olup olamadığını ve yüksek SAR dozlarına sahip akut RF-EMR maruziyetinin nörobiyolojik etkilerini araştırmışlardır. Ek olarak çalışmada, toksisite belirteci olarak beta amiloid 1-40 (A $\beta$ 1-40) peptit düzeyi de incelenmiştir. Çalışmada akut nörotoksisiteyi yeniden üretmek için erkek SpragueDawley sıçanlara $(n=68)$, yüksek SAR değerli RF-EMR maruziyeti uygulanmıştır. Çalışmadaki sıçanlar, üç farklı SAR dozuna maruz birakılacak (günde 15 dakika için 0 $\mathrm{W} / \mathrm{kg}, 1,5 \mathrm{~W} / \mathrm{kg}, 6 \mathrm{~W} / \mathrm{kg}$ ve 45 dakika için $6 \mathrm{~W} / \mathrm{kg}$ ) şekilde rastgele olarak dört bağımsız gruba $(n=14-20$ sıçan/grup) ayrılmıştır. Çalışmada, FC paradigması, EPM ve OF testleri kullanılarak, duyusal bellek, anksiyete benzeri davranış ve lokomotor aktivite değerlendirilmiştir. ELISA (enzyme linked immunosorbent assay) testi kullanılarak altı beyin bölgesindeki GFAP (toplam ve sitozolik fraksiyonları), myelin basic protein (MBP) ve $\mathrm{A} \beta$ 1-40 düzeyleri belirlenmiştir. Çalışma bulgularına göre, 1,5 W/kg SAR dozunda toplam GFAP, striatumda $(\%+114)$ artmıştır. Sitozolik GFAP, hipokampüs $(+\%+11)$ ve olfaktor bulb'de $(\%+46)$ artma 6 W/kg SAR dozunda (15 dakika) saptanmıştır. Ek olarak, $6 \mathrm{~W} / \mathrm{kg}$ SAR dozunda (15 dakika), kısa süreli bağlamsal hafızaya göre uzun süreli hafızada azalma gözlenmiştir. Fakat MBP veya A $\beta$ 1-40 ekspresyon düzeylerinde değişiklikler gözlenmemiştir. $\mathrm{Bu}$ sonuçlar, RF-EMR ile astrogliozis'in indüklendiğini gösterir iken, RF-EMR ile indüklenen astrogliozisin bellek üzerinde fonksiyonel sonuçları olduğunu ancak nöronal hasar üzerinde ikincil olarak etkili olduğunu düşündürmüştür. Ayrıca akut maruziyetten üç gün sonra serebral $A \beta$ 1-40 üzerinde RF-EMR'nın herhangi bir etkisi gözlenmemiştir. EPM testi sonuçlarına göre de RFEMR maruziyetinin anksiyete benzeri davranış ve lokomotor aktivite üzerine herhangi bir etkisi belirlenmemiştir (Tablo 1).

Bouji ve arkadaşları (16) çalışmalarında, merkezi sinir sistemi (MSS) üzerinde yaşlanmaya özgü nörobiyolojik hasarların cep telefonu RF-EMR ile olumsuz etkilerini araştırmak amacıyla, yaşı ı (22-24 aylık) ve genç (4-6 aylık) yetişkin erkek sıçanların baş bölgesine $900 \mathrm{MHz}$ RF-EMR maruziyeti (SAR: $6 \mathrm{~W} / \mathrm{kg}$, sınırlama roketlerinde bir ay boyunca 45 dakika/gün) uygulamışlardır. Çalışmada her bir yaş grubundaki sıçanlar; RF-EMR maruziyeti (45 dakika /gün, SAR: 6 W/kg, n=7-8/grup), sham-maruziyeti (45 dakika/gün, SAR: $0 \mathrm{~W} / \mathrm{kg}, \mathrm{n}=7-8 /$ grup), kafes kontrolü (davranışsal prosedürler, fakat maruz kalma roketlerinde kısıtlama 
olmayan, n=6/grup) olmak üzere üç bağımsız gruba ayrılmıştır. Siçanlarda yaşlanmaya özgü nörobiyolojik hasarları değerlendirmek için, uzaysal hafiza, duygusal (emosyonel) hafiza, anksiyete benzeri davranış, lokomotor aktivite, IL-1 $\beta$, IL-6, GFAP ve kortikosteron düzeyleri ölçülmüştür. Keşif ve anksiyete benzeri davranışlar, OF ve EPM testleri ile belirlenmiştir. Anksiyete benzeri davranışı ölçmek için OF testinde, düzeneğin merkez bölgesinde sıçanların harcadığı zaman, EPM testinde ise, açık ve yükseltilmiş bölgeler için sıçanların bu bölgelerden doğal kaçınması belirlenmiştir. Çalışma bulguları, RF-EMR maruziyeti ile yaşlanmaya özgü nörobiyolojik hasarların değişmediğini göstermiştir. EPM testinde yaşa bağlı olmaksızın (genç ve yaşlı yetişkin sıçanda), RF-EMR'a maruz kalan sıçanların anksiyete ile ilişkili davranışlarında anlamlı azalmalar gözlenir iken, OF testinde merkez aktivite paradigmasında, anksiyete ilişkili davranışlar saptanmamıştır. Ayrıca hipokampus ve korteks'deki sitokinlerin ekspresyonu ve GFAP üzerine RF-EMR etkisi de saptanmamıştır (Tablo 1).

Saikhedkar ve arkadaşları (17) çalışmalarında, uzun süreli cep telefonu kullanımının sıçan hipokampus'un sitolojik yapısı ve antioksidan durumlar ve bilişsel davranışlar (öğrenme, bellek) üzerindeki etkilerini araştırmışlardır. Çalışmalarında, yetişkin sıçanlar (30 günlük), 15 gün boyunca günde dört saat cep telefonları yoluyla $900 \mathrm{MHz}$ RF dalgalarına maruz bırakılmıştır. RF uygulamasının anksiyete, uzaysal öğrenme ve hafiza üzerindeki etkilerinin değerlendirilmesinde, OF, EPM, MWM, klasik labirent (classic maze) testleri kullanılmıştır. Ayrica beyin antioksidanları (SOD: süperoksit dismutaz, CAT: katalaz, GSH: redükte glutatyon, MDA: malondialdehit) ve nöronal hasar üzerine RF etkileri de değerlendirilmiştir. Çalışmada, RF maruziyetine uğramayan kontrol grubu ( $\mathrm{n}=3)$, deneysel sıçanlar ile aynı şekilde RF'a maruz kalan, fakat kafeslerine takılan cep telefonlarının kapalı tutulduğu sham grubu $(n=3)$ ve davranışsal, biyokimyasal ve histolojik çalışmalar için kullanılan $900 \mathrm{MHz}$ RF maruziyeti uygulanan (ortalama SAR: $0,99 \mathrm{~W} / \mathrm{kg})$ üç deney grubu $(n=21$, her biri $n=7)$ olarak sıçanlar toplam beş gruba ayrılmıştır. OF testinde, açık alan (merkezde kalma süresi) genel anksiyeteyi gösterir iken, bu açık alana farklı bölgelerden yapılan giriş sayısı anksiyöz lokomotor davranış parametresi olarak değerlendirilmiştir. Ayrıca defekasyon ve ürinasyon sayıları da anksiyete ile ilişkilendirilmiştir. OF testi bulgularında, deney grubu sıçanlarında, açık alanın tüm bölgelerindeki giriş sayıları ve aktivitelerinde artış gözlenmiştir. Deney grubu sıçanlarının açık alan düzeneğinin perifer kısımlarından girişlerdeki artışlar anlamlı $(p<0,05)$ olmasına rağmen, merkez girişlerdeki artışlar anlamlı bulunmamıştır. Bu sonucun yanı sıra, açık alanın periferin'deki harcanan zamanın deney grubunda daha uzun ölçülmesi, deney grubunda anksiyete seviyesinin yükseldiğini göstermiştir. Ek olarak, deney grubu siçanları kontrol grubu sıçanları ile karşılaştırıldığında, açık alanda daha hızlı anormal hareket modelleri sergilemişlerdir. Ayrıca deney grubu siçanlarda, artan stres seviyelerine atfedilen şahlanma (rearing) ve süslenme (grooming) hareketlerinde anlamlı artışlar $(\mathrm{p}<0,001)$ gözlenmiştir. Diğer gruplara göre deney grubu sıçanlarda, anlamlı olmayan $(p>0,05)$ defekasyon artışı gözlenir iken, ürinasyon sıklığı tüm gruplarda aynı bulunmuştur. EPM testinde, açık ve kapalı kol girişleri ve bu kollarda harcanan zaman ölçümü değerlendirilmiş ve bu değerlendirmede anksiyete'deki yoğun artış, açık kolların daha az tercihi ile ilişkilendirilmiştir. EPM testi bulgularına göre, bu testte açık koldan yapılan girişler, kontrol grubuna göre deney grubundaki sıçanlarda anlamlı derecede $(p<0,05)$ daha fazla bulunmuştur. Fakat merkezde ve kapalı kollarda gerçekleştirilen girişler, kontrol grubuna göre deney grubundaki sıçanlarda anlamlı olmayan derecede daha fazla belirlenmiştir. $\mathrm{Bu}$ sonuçlar, deney grubundaki sıçanların artan keşifsel davranışlar gösterdiğini ve böylece kontrol grubuna göre bu sıçanların daha az anksiyöz olduğu anlamına gelmektedir. Ayrıca, deney grubundaki sıçanlar, kapalı kollarda da uzun zaman harcayan kontrol grubu sıçanların aksine, kapalı kollardan kaçınarak açık kollarda daha uzun zaman harcamışlardır. Defekasyon ve ürinasyon açısından deney ve kontrol grubu arasında anlamlı bir fark gözlenmemesi, deney grubundaki sıçanların anksiyete'lerindeki azalmayı düşündürmüştür. Ayrıca keşifsel davranışlarda artışı ifade eden şahlanma (rearing) ve süslenme (grooming) hareketlerindeki artışlar anlamlı bulunmamıştır. EPM testi bulguları, deney grubundaki sıçanların kontrol grubundakilere göre daha az anksiyöz olduklarını ve dolayısıyla daha az korku belirtileri gösterdiklerini işaret etmiştir. Dolayısıyla EPM testi sonuçlarında, yetişkin sıçanlarda RF radyasyon maruziyeti ile anksiyete davranışında azalma gözlenmiştir. Fakat çalışmada, OF testi sonuçlarından yola çıkılarak, deney grubundaki sıçanlarda, kontrol ve sham grubundaki siçanlara göre anksiyete artışı ve daha zayıf öğrenme etkisi belirlenmiştir. Ayrıca deney grubu sıçanlarında, enzimatik ve enzimatik olmayan antioksidan seviyelerinde anlamlı değişimler ve lipid peroksidasyonunda artış gözlenmiştir. Histolojik incelemeler ile RF-EMR'a maruz kalma ile enzimatik ve enzimatik olmayan antioksidan'larda tükenme ve artan lipid peroksidasyonu nedeniyle reaktif oksijen türlerinin artan üretimine bağlı olarak spesifik hipokampal alt bölgeler (CA1, CA3, DG: dentat girus) ve serebral korteks'te yoğun nörodejenerasyon belirlenmiştir (Tablo 1).

Narayanan ve arkadaşları (18) çalışmalarında, erişkin erkek Wistar Albino siçanlarda ( $\mathrm{n}=36,150-160$ gr), 900 $\mathrm{MHz}$ RF-EMR maruziyetinin, emosyonalite ve lokomosyon üzerindeki etkilerini araştırmışlardır. Çalışmadaki sıçanlar, her grupta 12 sıçan olacak şekilde; kafeslerinde kalan grup I (kontrol), kapalı konumda cep telefonu maruziyeti uygulanan grup II (sham maruziyet) ve 28 gün boyunca günde bir saat aktif GSM cep telefonundan yayllan $900 \mathrm{MHz}$ RF-EMR maruziyeti (SAR: 1,15 W/kg) uygulanan grup III (RF-EMR maruziyet) olmak üzere toplam üç gruba ayrılmıştır. Deney süresi 28 gün boyunca uygulanmış olup, 29. günde tüm gruplardaki sıçanlar emosyonalite ve lokomosyon için test edilmiştir. EPM testi ile RF-EMR'a maruz kalan sıçanlarda, açık kola giriş, açık kolda harcanan süre ve açık kolda kat edilen mesafe yüzdelerinde anlamlı derecede azalmalar belirlenmiştir. Ayrıca RF-EMR'a maruz kalan sıçanlarda, şahlanma (rearing) ve süslenme (grooming) hareketlerinin frekanslarında da anlamlı 
azalmalar gözlenmiştir. EPM testi boyunca korku kaynaklı dışkılama sayısı, RF-EMR grupta daha fazla bulunmuştur. Lokomosyon sonuçlarında ise, kontrol grubu ile RF-EMR maruziyetine uğrayan sıçanlar arasında toplam kat edilen mesafe, toplam kol girişi, kapalı kol girişi ve EPM'nin açık kolları ve merkezindeki sıçanların paralellik indeks (PI: parallelism index) değerlerinde istatistiksel olarak anlamlı bir farklılık gözlenmemiştir. Sonuç olarak çalışmada, cep telefonu radyasyonunun, siçanlarda genel lokomosyonu etkilemeksizin, emosyonaliteyi anlamlı bir şekilde arttırdığı ortaya konulmuştur (Tablo 1).

Odaci ve arkadaşları (19) çalışmalarında, dişi sıçan yavrularının spinal kord ve motor davranışları üzerine doğum öncesi (prenatal) dönemde, 900 MHz RF-EMR etkisini araştırmışlardır. Çalışmada, Sprague-Dawley cinsi dişi gebe siçanlar, gebeliğin 13. ve 21. günleri arasında günde bir saat $900 \mathrm{MHz}$ RF-EMR'a maruz bırakılmıştır. Yirmi bir günlük olduklarında sıçan yavruları annelerinden çıkarılarak, bu yavrular kontrol $(n=13)$ ve RF-EMR $(n=10)$ grupları şeklinde yeni doğan siçan grubu olarak iki gruba ayrılmıştır. $\mathrm{Bu}$ sıçan gruplarının motor fonksiyonlarını değerlendirmek için rotarod testi, lokomotor aktivitelerini değerlendirmek için OF testi uygulanmıştır. Ayrıca sıçanların anksiyete'lerini değerlendirmek için OF testinde sıçanların defekasyon sayıları kaydedilmiştir. Çünkü deney sırasında artan defekasyon sayıları, anksiyete bulgusu olarak kabul edilmektedir. Çalışmanın 32. gününde sıçan yavruları kesilerek, üst torasik bölgedeki spinal kord çıkarılmıştır. Çalışmada rotarod test sonuçlarına göre, RF-EMR grubundaki sıçan yavrularının motor fonksiyonlarında anlamlı artışlar gözlenmiştir $(\mathrm{p}=0,037)$. Fakat sıçanların anksiyete'leri de dâhil olmak üzere OF testindeki tüm parametrelerinde anlamlı farklılıklar saptanmamıştır ( $>>0,05$ ). Ayrica 900 MHz RF-EMR maruziyetinin spinal kord'da patolojik değişiklere neden olarak, spinal kord gelişimini doğum öncesi (prenatal) dönemde etkilediği ortaya konulmuştur (Tablo 1).

Sokolovic ve arkadaşları (20) çalışmalarında, kronik mikrodalga radyasyon (MWR: microwave radiation) maruziyetinden sonra, sıçanlarda vücut kütlesi ve davranışlarındaki değişiklikler ile ışınlanan sıçanlarda melatoninin vücut kütlesi ve davranış üzerindeki etkilerini belirlemeyi amaçlamışlardır. Çalışmada yetişkin erkek Wistar Albino siçanlara $(n=40)$, cep telefonu tarafından üretilen $900 \mathrm{MHz}$ frekansında mobil iletişim için küresel sistem (GSM: Global System for Mobile Communication) ile maruziyet uygulanmıştır. Bu siçanlar, \% 0,9'luk serum fizyolojik verilen grup I (kontrol), melatonin (2 mg/kg, ip) verilen grup II (Mel), MWR maruziyeti uygulanan grup III (MWR) ve MW maruziyeti ile melatonin premedikasyonu uygulanan grup IV (MWR+ Mel) olarak toplam dört deney grubuna ayrılmıştır. Deney grubundaki sıçanlar (grup III ve IV) her gün dört saat MWR'a maruz birakılmış, tüm vücut SAR değeri olarak 0,043-0,135 W/kg kullanılmıştır. Vücut kütlesi (gram), deneyin başlangıcından itibaren MWR maruziyetinin 20., 40. ve 60. günlerinden sonra ölçülmüştür. OF testi kullanılarak, lokomotor aktivite ve radyasyon kaynağından uzaklaşma, şahlanma (rearing) ve süslenme (grooming) gibi stres ve/veya anksiyete ile ilişkili davranışlar değerlendirilmiştir. Çalışma bulgularında, kontrol grubu ile karşılaştırıldığında MWR'a maruz kalan sıçanlarda, 20, 40 ve 60 gün sonraki vücut kütlelerinde anlamlı azalmalar saptanmıştır $(\mathrm{p}<0,001)$. Ayrıca 20 gün sonunda, grup IV (MWR+ Mel)'deki sıçanların vücut ağırlığı, grup III (MWR)'deki sıçanların vücut ağrılıklarına göre anlamlı derecede yüksek bulunmuştur $(\mathrm{p}<0,05)$. MWR'a maruz kalan sıçanlarda 10 günlük maruziyetten sonra, anksiyete ilişkili davranışlar (ajitasyon, öfkelenme) gözlenmiştir. $\mathrm{Bu}$ gözlenen değişiklikler, 60 günlük MWR maruziyetinden sonra en şiddetli düzeylere ulaşmıştır. Radyasyon maruziyetine uğramış sıçanlara melatonin uygulanması, stres ve anksiyete ilişkili davranışlarda azalmalara neden olmuştur. Lokomotor aktiviteler, MWR'a maruz kalan sıçanlarda (grup III ve IV), maruz kalmayan sıçanlara (grup I ve II) göre hafif derecede azalmıştır. Keşifsel davranış sonuçlarına göre, MWR'a maruz kalmamış (grup I ve II) ve melatonin ön muamelesi gören MWR maruziyetli sıçanlar (grup IV)'a göre, MWR'a maruz kalan sıçanlarda (grup III), şahlanma (rearing) hareketinde azalma yoluyla değerlendirilen anlamlı derecede daha az keşifsel davranışlar gözlenmiştir. MWR'a maruz kalmış fakat melotinin verilmemiş sıçanlar (grup III), diğer gruplar ile karşılaştırıldığında (grup I, II ve IV), süslenme (grooming)'de daha fazla zaman harcamışlardır. Ayrıca, sıçanlar MWR kaynağından uzaklaştırıldıklarında, bu davranışsal değişiklikler daha az gözlenmiştir. Sonuç olarak MWR maruziyeti, sıçanlarda lokomotor aktivitede azalma ve anksiyete düzeylerinin artması gibi davranışsal değişikliklere ve vücut kitlesinde azalmalara neden olur iken, melatoninin, hem vücut ağırlığı hem de davranış değişiklikleri üzerindeki bu etkileri tersine çevirmiştir (Tablo 1).

Kumlin ve arkadaşları (21) çalışmalarında, genç erkek Wistar Albino siçanlarda ( $\mathrm{n}=72,60,0 \pm 0,1$ gr) сер telefonu ile üretilen GSM-900 MHz RF-EMR'a uzun süre maruz kalmanın, MSS üzerindeki morfolojik ve fonksiyonel etkilerini araştırmışlardır. Çalışmada, her bir grupta 24 sıçan olacak şekilde hayvanlar rastgele yüksek doz (SAR: 3,0 W/kg), düşük doz (SAR: 0,3 W/kg) ve sham maruziyeti olmak üzere toplam üç maruziyet grubuna ayrılmıştır. Bu sıçanlara beş hafta boyunca haftada beş gün olmak üzere, günde iki saat RF-EMR maruziyeti uygulanmış, her bir gruptan alınan altı sıçan histolojik incelemelere, her bir grupta geri kalan 18'er sıçan ise dört hafta boyunca davranış testine tabi tutulmuştur. Çalışmada davranış testleri olarak; lokomotor ve keşif aktiviteleri için OF, anksiyete için EPM, genel reaktivite ve dikkati test etmek için akustik (sesli) irkilme refleksinin PPI, uzaysal öğrenme ve hafızayı değerlendirmek için ise MWM testleri uygulanmıştır. MWM testi sonuçlarına göre, yalnızca RFEMR maruziyet grupları ile sham maruziyet grubu arasında anlamlı derecede gelişmiş öğrenme $(p=0,012)$ ve hafıza $(p=0,01)$ farklılıkları gözlenmiştir. Fakat OF, EPM ve akustik (sesli) irkilme refleksi PPI testi sonuçlarına göre, gruplar arasında, lokomotor, keşif aktiviteleri, anksiyete, genel reaktivite ve dikkat açısından herhangi bir farklılık belirlenmemiştir. İmmunohistokimyasal değerlendirme sonuçlarında ise, beyin morfolojisi, hipokampus'un dentat girusunda ölmekte olan nöron 
Tablo 1. $840 \mathrm{MHz}$ veya $900 \mathrm{MHz}$ RF/MW-EMR maruziyetlerine ait literatür çalışmaları ve sonuçları

\begin{tabular}{|c|c|c|c|c|c|c|c|c|c|}
\hline $\begin{array}{l}\text { Yazar ve } \\
\text { Yayın Yılı } \\
\text { (Kaynak no) }\end{array}$ & $\begin{array}{l}\text { Çalıșlan } \\
\text { Frekans } \\
\text { (MHz) }\end{array}$ & $\begin{array}{l}\text { Spesifik } \\
\text { absorbsiyon } \\
\text { oranı } \\
\text { (SAR, W/kg) } \\
\end{array}$ & $\begin{array}{lr}\text { Güç } & \text { yoğunluğu } \\
\text { veya } & \text { elektrik } \\
\text { alan } & \end{array}$ & $\begin{array}{l}\text { Maruziyet } \\
\text { sistemi } \\
\text { veya kurulumu }\end{array}$ & $\begin{array}{l}\text { Maruziyet } \\
\text { süresi }\end{array}$ & $\begin{array}{l}\text { Maruziyet bölgesi } \\
\text { (tüm } \\
\text { vücut/baş/karın } \\
\text { (abdomen)) } \\
\end{array}$ & $\begin{array}{l}\text { Hayvan modeli } \\
\text { (yaş) }\end{array}$ & Çalışılan parametreler & Çalışmanın sonuçları \\
\hline $\begin{array}{lr}\text { Daniels } & \text { ve } \\
\text { ark. } & 2009 \\
(12) & \end{array}$ & $840 \mathrm{MHz}$ & Bildirilmemiştir. & $60 \mu \mathrm{W} / \mathrm{m}^{2}$ & $\begin{array}{l}840 \quad \mathrm{MHz} \\
\text { yayınlayan } \\
\text { radyofrekans } \\
\text { sinyal jenaratör }\end{array}$ & $\begin{array}{l}13 \text { gün boyunca } \\
3 \text { saat/gün }\end{array}$ & Tüm vücut & $\begin{array}{l}\text { Dişi ve erkek } \\
\text { Sprague -Dawley } \\
\text { sıçan yavruları } \\
\text { (2-14 günlük) }\end{array}$ & $\begin{array}{lr}\text { Anksiyete } & \text { benzeri } \\
\text { davranış, } & \text { emosyonel } \\
\text { stres, ögrrenme, hafiza, } & \text { ve } \\
\text { ve } & \text { kortikosteron } \\
\text { düzeyleri } & \end{array}$ & $\begin{array}{l}\text { EMR maruziyeti, özellikle erkek sıçanlarda, } \\
\text { lokomotor aktivitede azalma, süslenme (grooming) } \\
\text { ve donma davranışlarında artma ile anksiyete } \\
\text { benzeri davranışa neden olmuştur. Ayrıca, kontrol } \\
\text { grubu dişi sıçanlara göre, EMR'a maruz kalan dişi } \\
\text { sıçanlarda, kortikosteron düzeyleri de arttırmıştır. }\end{array}$ \\
\hline $\begin{array}{l}\text { Petitdant } \\
\text { ark. } \\
\text { ark } \\
(13)\end{array}$ & $900 \mathrm{MHz}$ & $\begin{array}{l}\text { Fetus vücudu için } \\
0 \mathrm{~W} / \mathrm{kg}, 0,7 \mathrm{~W} / \mathrm{kg} \text {, } \\
2,6 \quad \mathrm{~W} / \mathrm{kg} \\
\text { kullanılmıştır. }\end{array}$ & $\begin{array}{l}\text { Puls gücü: } 0 \mathrm{~W} \text {, } \\
1 \mathrm{~W}, 4 \mathrm{~W}\end{array}$ & $\begin{array}{lr}900 \mathrm{MHz} & \text { EMA } \\
\text { bant } & \text { üreten } \\
\text { GSM } & \text { güç } \\
\text { kaynağ1 } & \end{array}$ & $\begin{array}{l}\text { Gestasyonel } \\
\text { dönem boyunca }\end{array}$ & $\begin{array}{lr}\text { Gebe } & \text { siçanların } \\
\text { abdomen } & \text { bölgesi, } \\
\text { fetüsun tüm vücudu }\end{array}$ & $\begin{array}{lr}\text { Dişi } & \text { Sprague- } \\
\text { Dawley } & \text { gebe } \\
\text { siçan } & \end{array}$ & $\begin{array}{lr}\text { Anksiyete } & \text { ilişkili } \\
\text { davranışlar, emosyonel } \\
\text { hafiza, IL-1 } \beta, \quad \text { GFAP } \\
\text { düzeyleri }\end{array}$ & $\begin{array}{l}\text { Maternal immün aktivasyonu, sensorimotor } \\
\text { geçidinde SAR bağımlı bir azalmayı tetiklemiştir. } \\
\text { Maternal RF-EMR, ergenlerde yeni ortamın } \\
\text { sunumunda SAR'a bağımlı olarak OF testinde } \\
\text { yatay aktiviteyi azaltmıştır. Fakat gestasyonel RF- } \\
\text { EMR ve/veya LPS uygulamalarında veya yas ile } \\
\text { etkileşimlerinde EPM testinin açı kolunda } \\
\text { harcanan zaman yüzdeleri açısından herhangi bir } \\
\text { etki saptanmamıștır. }\end{array}$ \\
\hline $\begin{array}{l}\text { Petitdant } \\
\text { ark. } \\
\text { (14) }\end{array}$ & $900 \mathrm{MHz}$ & $\begin{array}{l}0 \mathrm{~W} / \mathrm{kg} \\
1,5 \mathrm{~W} / \mathrm{kg} \\
6 \mathrm{~W} / \mathrm{kg}\end{array}$ & Bildirilmemiştir. & $\begin{array}{lr}900 \mathrm{MHz} & \text { EMA } \\
\text { bant } & \text { üreten } \\
\text { GSM } & \text { güç } \\
\text { kaynağ1 } & \end{array}$ & $\begin{array}{l}\text { Postnatal (P) } \\
\text { dönemde, } \\
\text { P32'den P62'ye } \\
\text { kadar, haftada } \\
\text { beş gün olacak } \\
\text { șekilde } \quad 45 \\
\text { dakika } \quad\end{array}$ & Baş bölgesi & $\begin{array}{l}\text { Dişi hamile sıçan } \\
\text { ([GD] gün } 9 \pm 1 \text { ) } \\
\text { Erkek Sprague- } \\
\text { Dawley sıçan }\end{array}$ & $\begin{array}{lr}\text { Anksiyete } & \text { benzeri } \\
\text { davranışlar, } & \text { yenilik } \\
\text { (novelty) algisı, duygusal } \\
\text { (emosyonel) rafiza, } \\
\text { astrosit reaktivitesi, } \\
\text { GFAP düzeyleri }\end{array}$ & $\begin{array}{l}\text { RF-EMR maruziyetinin anksiyete bereri } \\
\text { davranışlar üzerinde herhangi bir } \\
\text { etkisi de } \\
\text { belirlenmemiştir. Ergenlik dönemi RF-EMR } \\
\text { maruziyeti, sıçanların astrosit reaktivitesi, yenilik } \\
\text { (novelty) algısı, duygusallık düzeyleri ve GFAP } \\
\text { seviyelerini değisstirmemiştir. Ergen siçanlar } \\
\text { gestasyonel inflamasyon sonrası veya } \\
\text { nöroinflamasyon süresi boyunca RF-EMR } \\
\text { maruziyetine daha duyarlı olmuşlardır. }\end{array}$ \\
\hline $\begin{array}{l}\text { Barthélémy } \\
\text { ve ark. } 2016 \\
\text { (15) }\end{array}$ & $900 \mathrm{MHz}$ & $\begin{array}{l}0 \mathrm{~W} / \mathrm{kg} \\
1,5 \mathrm{~W} / \mathrm{kg} \\
6 \mathrm{~W} / \mathrm{kg}\end{array}$ & Bildirilmemiştir. & $\begin{array}{l}900 \quad \mathrm{MHz} \\
\text { yayinlayan } \\
\text { radyofrekans } \\
\text { jenaratör }\end{array}$ & $\begin{array}{lr}0 \text { W/kg, } & 1,5 \\
W / k g \text { ve } & 6 \\
W / K g \text { için } & 15 \\
\text { dakika/gün, } & 6 \\
\text { W/kg için } & 45 \\
\text { dakika/gün } & \end{array}$ & Tüm vücut & $\begin{array}{lr}\text { Erkek } & \text { Sprague- } \\
\text { Dawley } & \text { siçan } \\
\text { (6 haftalık) } & \end{array}$ & $\begin{array}{lr}\text { Anksiyete } & \text { benzeri } \\
\text { davranıs, } & \text { emosyonel } \\
\text { bellek, } & \text { lokomotor } \\
\text { aktivite, beta amyloid 1- } \\
40 \text { (A } \beta \text { 1-40), } \\
\text { MBPAP ve } \\
\text { MBP̈zeyleri }\end{array}$ & $\begin{array}{l}\text { RF-EMR maruziyetinin anksiyete benzeri davranış } \\
\text { ve lokomotor aktivite üzerine herhangi bir etkisi } \\
\text { belirlenmemiştir. RF-EMR ile astrogliozis } \\
\text { indüklenmiştir. } \\
\text { striatumda } 1,5 \text { WFAP'nı toplam miktarı maruziyette, sitozolik } \\
\text { miktarı hipokampus ve olfaktor bulb'de } 6 \mathrm{~W} / \mathrm{kg}(15 \\
\text { dakika) maruziyette artmıştır. Ayrıca } 6 \mathrm{~W} / \mathrm{kg}(15 \\
\text { dakika) maruziyette uzun süreli bellek azalmıştır. }\end{array}$ \\
\hline
\end{tabular}

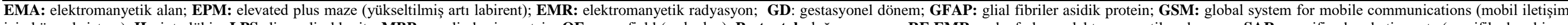

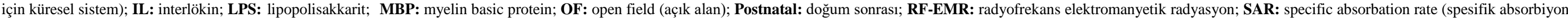
oran1); UHF: ultra-high frequency (ultra yüksek frekans) 
Tablo 1. $840 \mathrm{MHz}$ veya $900 \mathrm{MHz}$ RF/MW-EMR maruziyetlerine ait literatür çalışmaları ve sonuçları (devamı)

\begin{tabular}{|c|c|c|c|c|c|c|c|c|c|}
\hline $\begin{array}{l}\text { Yazar ve } \\
\text { Yayın Yılı } \\
\text { (Kaynak no) }\end{array}$ & $\begin{array}{l}\text { Çalışılan } \\
\text { Frekans } \\
\text { (MHz) }\end{array}$ & $\begin{array}{l}\text { Spesifik } \\
\text { absorbsiyon } \\
\text { oranı } \\
\text { (SAR, W/kg) }\end{array}$ & $\begin{array}{lr}\text { Güç } & \text { yoğunluğu } \\
\text { veya } & \text { elektrik } \\
\text { alan } & \end{array}$ & $\begin{array}{l}\text { Maruziyet } \\
\text { sistemi } \\
\text { veya kurulumu }\end{array}$ & $\begin{array}{l}\text { Maruziyet } \\
\text { süresi }\end{array}$ & $\begin{array}{l}\text { Maruziyet bölgesi } \\
\text { (tüm } \\
\text { vücut/baş/karın } \\
\text { (abdomen)) }\end{array}$ & $\begin{array}{l}\text { Hayvan modeli } \\
\text { (yaş) }\end{array}$ & Çalş̧ılan parametreler & Çalışmanın sonuçları \\
\hline $\begin{array}{l}\text { Bouji ve ark. } \\
2016 \text { (16) }\end{array}$ & $900 \mathrm{MHz}$ & $6 \mathrm{~W} / \mathrm{kg}$ & Bildirilmemiştir. & $\begin{array}{l}900 \quad \mathrm{MHz} \\
\text { yayınlayan } \\
\text { radyofrekans } \\
\text { jenaratör }\end{array}$ & $\begin{array}{l}1 \text { ay boyunca } \\
45 \text { dakika/gün }\end{array}$ & Baş bölgesi & 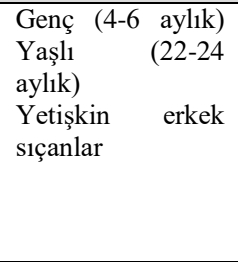 & $\begin{array}{lr}\text { Anksiyete, uzaysal ve } \\
\text { emosyonel } & \text { hafiza, } \\
\text { lokomotor iliskili } \\
\text { davranıslar, interlökinler } \\
\text { (IL-1 } \beta \text {, IL-6), GFAP ve } \\
\text { kortikosteron düzeyleri }\end{array}$ & $\begin{array}{l}\text { RF-EMR'a maruz kalmış sıçanlarda EPM testine } \\
\text { göre anksiyete ile ilişkili davranışlarda belirgin } \\
\text { azalmalar gözlenmiştir. Fakat OF testinde merkez } \\
\text { aktivite paradigmasında, anksiyete ilişkili } \\
\text { davranışlar gözlenmemiştir. Yaşlı sıçanlarda } \\
\text { uzaysal öğrenme ve keşif yeteneklerinde eksiklikler } \\
\text { belirlenmiștir. Hipokampal IL'ler ve kortikal IL- } \\
1 \beta \text { 'da artş̧lar saptanmışstır. }\end{array}$ \\
\hline $\begin{array}{l}\text { Saikhedkar } \\
\text { ve ark. } 2014 \\
\text { (17) }\end{array}$ & $900 \mathrm{MHz}$ & $0,9 \mathrm{~W} / \mathrm{kg}$ & Bildirilmemiştir. & $\begin{array}{l}\text { Cep telefonu } \\
\text { (Spice S-5110) }\end{array}$ & $\begin{array}{l}15 \text { gün boyunca } \\
4 \text { saat/gün }\end{array}$ & Tüm vücut & $\begin{array}{lr}\text { Genç } & \text { yetişkin } \\
\text { erkek } & \text { Wistar } \\
\text { Albino } & \text { Siçan } \\
\text { (30 günlük) } & \end{array}$ & $\begin{array}{l}\text { Anksiyete, uzaysal } \\
\text { öğrenme ve hafiza, beyin } \\
\text { antioksidant durumlar ve } \\
\text { beyindeki nöronal hasar }\end{array}$ & $\begin{array}{l}\text { RF-EMR maruziyeti ile anksiyete’de artma, } \\
\text { uzaysal öğrenme ve hafizada zayıflama } \\
\text { saptanmıştr. Ayrica radyasyon maruziyeti ile lipid } \\
\text { peroksidasyonunda artış ve hipokampal alt } \\
\text { bölgelerde ve serebral kortekste nörodejeneratif } \\
\text { hücreler gözlenmiştir. }\end{array}$ \\
\hline \begin{tabular}{lr}
\multicolumn{3}{l}{ Narayanan ve } \\
ark. 2013 \\
(18)
\end{tabular} & $900 \mathrm{MHz}$ & $1,15 \mathrm{~W} / \mathrm{kg}$ & $146,60 \mu \mathrm{W} / \mathrm{cm}^{2}$ & $\begin{array}{ll}\text { GSM } & \text { сер } \\
\text { telefonu } & \end{array}$ & $\begin{array}{l}28 \text { gün boyunca } \\
1 \text { saat/gün }\end{array}$ & Tüm vücut & $\begin{array}{l}\text { Erkek Wistar } \\
\text { Albino siçan (6-8 } \\
\text { haftalık) }\end{array}$ & $\begin{array}{ll}\begin{array}{l}\text { Anksiyete, } \\
\text { davranışlar }\end{array} & \text { lokomotor } \\
\end{array}$ & $\begin{array}{l}\text { RF-EMR maruziyeti, erişkin sıçanlarda, } \\
\text { emosyonalite benzeri davranışarda artmaya neden } \\
\text { olur iken, genel lokomosyon ilisskili parametrelerde } \\
\text { anlamlı bir değişim oluşturmamıştır. }\end{array}$ \\
\hline $\begin{array}{l}\text { Odaci ve ark. } \\
2013 \text { (19) }\end{array}$ & $900 \mathrm{MHz}$ & Bildirilmemiştir. & $10 \mathrm{~V} / \mathrm{m}$ & UHF osilatör & $\begin{array}{lr}\text { Gebeliğin } 13 . \\
\text { gününden } 21 . \\
\text { gününe kadar } \\
1 \text { saat/gün } \\
\end{array}$ & Tüm vücut & $\begin{array}{ll}\text { Dişi sıçanlar } & (6-8 \\
\text { haftalık) } & \text { ve } \\
\text { yavruları } & \end{array}$ & $\begin{array}{lll}\text { Anksiyete, } & \text { motor } \\
\text { fonksiyonlar } & \text { ve } & \text { spinal } \\
\text { kord yap } 1 & & \end{array}$ & $\begin{array}{l}\text { RF-EMR maruziyeti ile, anksiyete'de değişim } \\
\text { gözlenmemiştir. Fakat EMR maruziyeti sonucu } \\
\text { lokomotor aktivitede artma, spinal kord'da } \\
\text { patolojik değişiklikler saptanmıştır. }\end{array}$ \\
\hline \begin{tabular}{l}
\multicolumn{2}{l}{ Sokolovic ve } \\
ark. 2012 \\
(20)
\end{tabular} & $900 \mathrm{MHz}$ & $0,043-0,135 \mathrm{~W} / \mathrm{kg}$ & Bildirilmemiştir. & $\begin{array}{ll}\text { GSM } & \text { сер } \\
\text { telefonu } & \end{array}$ & $\begin{array}{l}60 \text { gün boyunca } \\
4 \text { saat/gün }\end{array}$ & Tüm vücut & $\begin{array}{lr}\text { Yetişkin } & \text { erkek } \\
\text { Wistar } & \text { Albino } \\
\text { siçan } & \end{array}$ & $\begin{array}{lr}\text { Anksiyete } & \text { ilişkili } \\
\text { davranıs, } & \text { lokomotor } \\
\text { aktivite, şahlanma ve } \\
\text { süslenmer (tımarlanma) } \\
\text { hareketleri, vücut } \\
\text { ăgllığının (gram) artışı } \\
\end{array}$ & $\begin{array}{l}\text { MWR maruziyeti, siçanlarda lokomotor aktivitede } \\
\text { azalma, anksiyete düzeylerinde artma ve vücut } \\
\text { kitlesinde azalmalara neden olur iken, melatonin } \\
\text { uygulaması, hem vücut ağırllğı hem de davranış } \\
\text { değişiklikleri üzerindeki etkileri tersine çevirmiştir. }\end{array}$ \\
\hline $\begin{array}{lr}\text { Kumlin } & \text { ve } \\
\text { ark. } & 2007 \\
(21) & \end{array}$ & $900 \mathrm{MHz}$ & $\begin{array}{l}0,3 \mathrm{~W} / \mathrm{kg} \\
3,0 \mathrm{~W} / \mathrm{kg}\end{array}$ & Bildirilmemiştir. & $\begin{array}{ll}900 \mathrm{MHz} & \\
\text { GSM } & \text { сер } \\
\text { telefonu } & \end{array}$ & $\begin{array}{lr}5 & \text { hafta } \\
\text { boyunca, } & 5 \\
\text { gün/hafta } & \text { ve } \\
2 \text { saat/gün } & \end{array}$ & Tüm vücut & $\begin{array}{l}\text { Genç erkek Wistar } \\
\text { Albino } \quad \text { siçan } \\
\text { (21 günlük) }\end{array}$ & $\begin{array}{l}\text { Anksiyete, lokomotor ve } \\
\text { keşif akitiviteleri, genel } \\
\text { reaktivite, dikkat, } \\
\text { uzaysal ögrenme ve } \\
\text { hafiza, beyin morfolojisi }\end{array}$ & $\begin{array}{l}\text { RF-EMR'un anksiyete, genel reaktivite, dikkat, } \\
\text { lokomotor ve keşif aktiviteleri ile beyin morfolojisi } \\
\text { üzerine etkisi saptanmamıştır. RF-EMR maruziyet } \\
\text { grupları ile sham maruziyet grubu arasında anlaml } \\
\text { derecede gelişsmiş öğrenme }(\mathrm{p}=0,012) \text { ve hafiza } \\
(\mathrm{p}=0,01) \text { farkll1lkları gözlenmiştir. }\end{array}$ \\
\hline
\end{tabular}


veya yeni üretilen nöron sayıları ile kan beyin bariyeri açıklığı üzerinde anlamlı etkiler saptanmamıştır. Sonuç olarak çalışmada, cep telefonu radyasyonun beyin gelişimi üzerinde ciddi bir tehdit olmadığı, fakat ilginç olarak GSM-900 MHz RF-EMR maruziyetinin öğrenme ve hafıza gelişiminde etkilerinin olabileceği ileri sürülmüştür (Tablo 1).

\section{B. 905 MHz, 915 MHz veya 940 MHz EMR}

Maruziyetlerine Ait Literatür Çalışmaları

Khirazova ve arkadaşları (22) çalışmalarında, beyaz outbred cinsi dişi ve erkek sıçanların ( $\mathrm{n}=20,260$-350 gr), iki saat boyunca GSM-905 MHz EMR'a maruz kalmasının, stres oluşturan ve stres sınırlayıcı sistemleri ifade eden temel davranışsal modeller ve biyokimyasal parametreler üzerindeki etkilerini araştırmışlardır. Çalışmada, deney grubundaki sıçanlar $(n=10)$ iki saat EMR maruziyetine bırakılır iken, kontrol grubundaki sıçanlar (n=10) aynı koşullarda EMR almaksızın iki saat geçirmişlerdir. Deney grubundaki sıçanlar, EMR'un davranış üzerindeki etkileri ifade eden, akut (grup 1) ve kronik (grup 2) etkiler olmak üzere iki etki grubu şeklinde değerlendirilmiştir. OF testi ile sıçan davranış aktivitesinin kaydı, EMR maruziyetinden sonra, beş dakika (grup 1) veya 24 saat (grup 2) içinde başlatılmıştır. Kaydedilen sıçan davranış parametrelerinden lokomotor, yönelim ve keşif aktiviteleri; dikey-yatay motor aktivite, duvardan adım çıkış sayıları ve merkez ziyaretlerin ölçülmesi ile belirlenirken iken, anksiyete düzeyi parametresi ise; defekasyon sayısı ve toplam donma sürelerinin (saniye) ölçülmesi ile değerlendirilmiştir. Çalışma bulgularında $905 \mathrm{MHz}$ EMR maruziyeti, dişi sıçanlarda anksiyete'de artış, lokomotor, yönelim ve keşif aktivitelerinde azalma oluştururken, erkek sıçanlarda, yönelim, anksiyete'de azalma, keşif ve lokomotor aktivitelerinde artma sergilemiştir. Hem erkek hem de dişi sıçanlarda glukokortikoid düzeyleri ve antioksidan sistem aktiviteleri artmıştır. $\mathrm{Bu}$ çalışmada, akut etkilere ek olarak, maruziyetten bir gün sonra erkek ve dişi sıçanlarda radyasyonun gecikmiş etkileri de gözlenmiştir. Ayrıca glukokortikoid plazma düzeylerinin analizlerinde, akut dönemde (hormon seviyelerinde artışlar), dişi ve erkek sıçanlarda birlikte yönlendirilmiş kaymalar da gözlenmiştir. EMR'nun gecikmiş etkileri (24 saat), yalnızca erkek sıçanlarda glukokortikoid düzeylerinde azalmaya neden olmuştur. EMR'nun antioksidan savunma sistemi (ADS: anti-oxidant defense system) parametreleri üzerindeki etkilerinin değerlendirilmesinde, 20 dakika EMR sonrası erkek sıçanlarda lipid hidroperoksit seviyelerinin kontrole kıyasla azaldığ belirlenmiştir. Dişi sıçanlarda EMR'dan sonra 24 saatte SOD benzeri plazma aktivitesinde artış saptanmıştır. Bu sonuçlar, deney hayvanlarında, ADS reaksiyon yanıtının gelişim hızında, EMR maruziyeti ve cinsiyet farklılıklarının önemli rol oynadığını ispatlamıştır. Fakat EMR maruziyetinden sonraki akut dönemde, stres oluşturan sistemde artan aktiviteye karşı ADS uyarısında gözlenen belirtilerin mekanizmaları açıklığa kavuşturulamamıştır. Sonuç olarak çalışmada, $905 \mathrm{MHz}$ EMR'a uzun dönem maruziyetin (en az 24 saat), sıçanlarda stres oluşturan ve stres sinırlayıcı sistemlerin aktiviteleri yanı sıra, anksiyete, lokomotor, yönelim ve keşif aktiviteleri üzerinde önemli etkilere sahip olduğu gösterilmiştir (Tablo 2).

Nittby ve arkadaşları (23) çalışmalarında, Fischer 344 cinsi dişi ve erkek sıçanlarda $(n=56$, yaklaşı $200-350$ gr), cep telefonu ile üretilen GSM-900 MHz EMR'a kronik maruziyetin uzun vadeli etkilerini araştırmışlardır. $\mathrm{Bu}$ siçanlara ( $\mathrm{n}=32)$ GSM-900 $\mathrm{MHz}$ cep telefonundan yayılan termal etki oluşturmayan düşük (SAR: 0,6 $\mathrm{mW} / \mathrm{kg}, \mathrm{n=16}$ ) ve yüksek dozlarda (SAR: $60 \mathrm{~mW} / \mathrm{kg}$, $\mathrm{n}=16$ ) iki farklı SAR değerine sahip RF-EMR maruziyeti toplam 55 hafta boyunca haftada bir kez iki saat olacak şekilde uygulanmıştır. Diğer 16 sıçan sham maruziyeti ve sekiz sıçan ise kafesinden hiç ayrılmayan kontrol grubu olarak incelenmiştir. GSM maruziyetinin hayvanların keşif davranışı ve anksiyete düzeyleri üzerine etkileri OF testi ile bilişsel (kognitif) davranışlar üzerine etkileri ise epizodik benzeri hafiza (ELM: episodic-like memory) testi ile belirlenmiştir. OF testinde, sıçan daha ileri hareket etmeden önce açık alanın merkezinde geçirilen süre (merkezde kalma süresi) genel anksiyete'nin bir göstergesi olup, daha az anksiyete'li sıçanlarda bu süre kısalmaktadır. Ayrıca defekasyon ve ürinasyon'da anksiyete ile ilişkili olarak değerlendirilmiştir. Çalışmada, sıçanların açık alana daha alışkın hale geldikleri sonraki günlerde anksiyete'nin azaldığı, fakat erkek sıçanların dişi sıçanlardan daha anksiyetik oldukları belirlenmiştir. Ek olarak, sıçanlar OF testi çevresine daha alışkın oldukları sonraki günlerde doğal bir reaksiyon gösterdiklerinden defekasyon ve ürinasyonları da azalmıştır $(\mathrm{p}<0,0001)$. Bu bulgular ile birlikte, kontrol grubuna ait sıçanların ürinasyonları, sham ve GSM maruz kalan sıçanların ürinasyonlarına göre daha düşük düzeyde azalma göstermiştir ( $\mathrm{p}=0,002)$. Bu sonuç, diğer gruptaki hayvanlar (sham ve GSM maruziyetli sıçanlar) ile karşılaştırıldığında, sürekli kafeslerinde tutulan deneyimsiz kontrol grubu sıçanlarının daha yüksek anksiyete düzeylerine sahip olduğunu ortaya koymuştur. Ayrıca ürinasyon, erkek sıçanlarda dişi sıçanlara göre daha az azalmıştır ( $p=0,025)$. OF testi ile değerlendirilen keşif davranışı açısından, gruplar arasında farklılık gözlenmemiştir. Ayrıca ELM testi bulgularına göre, iki farklı SAR değerli $(0,6 \mathrm{~mW} / \mathrm{kg}, 60 \mathrm{~mW} / \mathrm{kg})$ GSM-900 mikrodalga'ya uzun süreli maruziyetin, epizodik hafiza fonksiyonlarını anlamlı derecede $(p=0,02)$ azalttığ 1 belirlenmiş olmasının yanı sıra, düşük ve yüksek SAR değerli GSM maruziyetli sıçanlar arasında epizodik hafıza açısından istatistiksel olarak anlamlı farklılıklar gözlenmemiştir $(p=0,19)$. Bu sonuçlar, biyolojik etkilerin daha yüksek maruziyet seviyeleri ile mutlaka artmadı̆̆ güç yoğunluğuna bağlı olabileceği şeklinde açıklanmıştır (Tablo 2).

Ahmadi ve arkadaşları (24) çalışmalarında, erkek Wistar Albino sıçanlarda ( $\mathrm{n}=28$, ortalama $190 \pm 10 \mathrm{gr}), 940 \mathrm{MHz}$ frekanslı cep telefonu radyasyonunun serum kortizol seviyeleri ve anksiyete düzeyi üzerine etkilerini araştırmışlardır. Çalışmadaki sıçanlar her bir grupta yedi siçan olacak şekilde kontrol grubu (radyasyon almayan), deney grubu 1 (bir saat/gün maruz kalma), deney grubu 2 (üç saat/gün radyasyona maruz kalma), deney grubu 3 (altı saat/gün maruz kalma) olmak üzere toplam dört gruba ayrılmıştır. Sekiz hafta sonra anksiyetenin değerlendirilmesinde EPM testi kullanılmış, bu testte açık kola giriş sayısı ve bu kollarda geçen sürenin yüzdesi 
hesaplanmıştır. Serum kortizol seviyeleri, ELFA (Enzyme-Linked Fluorescent Assay) yöntemi kullanılarak belirlenmiştir. Deney grubu 3'deki sıçanların (altı saat/gün) serum kortizol seviyelerinin, kontrol grubundaki sıçanlara ait değerlere göre anlamlı derecede arttığ 1 belirlenmiştir $(p<0,05)$. Fakat kortizol seviyeleri açısından deney grupları 1 ve 2 ile kontrol grupları karşılaştırıldığında, anlamlı bir fark gözlenmemiştir. EPM testi sonuçlarında ise, tüm deney gruplarında, kontrol gruplarına göre, açık kollarda harcanan zaman yüzdesi ve açık kollara giriş yüzdesi anlamlı derecede azalmıştır (her biri için $\mathrm{p}<0,001$ ). Böylece açık kola giriş sayısı ve geçen süredeki azalma sonucu, tüm deney gruplarında (deney grubu 1, 2 ve 3), kontrol grubuna göre anksiyetenin arttığını göstermiştir. Çalışma bulguları, 940 $\mathrm{MHz}$ cep telefonu radyasyonuna maruz kalmanın önemli bir çevresel stres faktörü olarak, kortizol seviyelerinde artış ile birlikte anksiyete düzeylerinde artışa yol açtığını da ortaya koymuştur (Tablo 2).

\section{1800 MHz EMR Maruziyetine Ait Literatür Çalışmaları}

Zhang ve arkadaşları (25) çalışmalarında, genç erkek C57BL/6 cinsi farelerde ( $n=70$, dört haftalık), 28 gün boyunca günde altı saat $1800 \mathrm{MHz}$ RF-EMR maruziyetinin, duygusal (emosyonal) davranış ve uzaysal hafıza üzerindeki etkilerini araştırmışlardır. Çalışmadaki fareler, rastgele olarak RF-maruziyet ve sham-maruziyet grupları olarak toplam iki deney grubuna ayrılmıştır. Farelerin anksiyete benzeri davranışları; OF, EPM testleri ile değerlendirilirken, depresyon benzeri davranışları; sukroz tercih testi (SPT: sucrose preference test), kuyruk süspansiyon testi (TST: tail suspension test) ve zorunlu yüzme testi (FST: forced swim test) ile değerlendirilmiştir. Ayrıca sıçanların uzaysal hafıza ve hafıza becerileri ise MWM deneyleri ile incelenmiştir. Aminoasit nörotransmitterlerinin düzeyleri sıv1 kromatografi-kütle spektrometrisi (LC-MS: liquid chromatography-mass spectrometry) ile belirlenmiştir. Beyin histolojisi, hematoksilen-eozin (H\&E: hematoxylin-eosin) boyama ile incelenmiştir. Çalışma bulgularında RF-EMR maruziyetinden sonra, depresyon benzeri davranışlar, uzaysal hafıza yeteneği ve beyin histolojisinde belirgin bir değişim saptanmamıştır. Fakat RF-EMR maruziyetinden sonra, anksiyete benzeri davranışlar artar iken, korteks ve hipokampüsteki GABA (gama aminobütirik asit) ve aspartik asit (Asp) düzeylerinde anlamlı derecede azalmalar gözlenmiştir. $\mathrm{Bu}$ bulgular doğrultusunda çalışmada, ergen erkek farelerde dört hafta boyunca $1800 \mathrm{MHz}$ RF-EMR maruziyetinin, depresyon benzeri davranış, uzaysal hafıza ve beyin histolojisini etkilemediği, fakat GABA ve Asp gibi aminoasit nörotransmitterlerinde anlamlı azalmalara neden olarak, anksiyete düzeylerini arttırabileceği gösterilmiştir (Tablo 2).

Júnior ve arkadaşları (26) çalışmalarında, yetişkin erkek Wistar Albino sıçanlarda ( $\mathrm{n}=12,60$ günlük), $1800 \mathrm{MHz}$ cep telefonu radyasyonunun anksiyete, çalışma belleği homeostazı, stres profillerinin gelişimi üzerine etkilerini belirlemeyi amaçlamışlardır. Çalışmadaki sıçanlar rastgele seçilerek, $1800 \mathrm{MHz}$ frekansında sinyal üreten GSM cep telefonundan yayılan radyasyona üç gün boyunca, her iki dakika da bir 25 saniye süreli cep telefonu çağrıları şeklinde maruz kalan deney grubu (n=6) ve RF-EMR maruziyetine uğramayan kontrol (sham maruziyet) grubu $(n=6)$ olmak üzere toplam iki gruba ayrılmıştır. Üç gün maruziyet sonrası gruplara davranışsal testlerden $O F$ ve nesne tanıma testleri uygulanmıştır. OF testi bulgularında, sıçanların OF düzeneğinin açık alan merkezinde kalma süreleri açısından gruplar arasında anlamlı bir farklılık belirlenmemiştir. Fakat kontrol grubuna göre RF-EMR'a maruz kalan siçanlarda stres ile ilişkili olarak incelenen, savunma ve keşifsel davranışlarını ifade eden immobilizasyon (hareketsizlik) süresi ve şahlanma (rearing) hareketi frekansında anlamlı artışlar gözlenmiştir. Çalışma bulgularında, RF-EMR'a maruz kalan sıçanlarda anksiyete/anksiyete benzeri davranışlarının etkilenmediği ve çalışma belleği bozukluğu gözlenmediği, fakat bu maruziyetin stres davranış eylemlerine neden olabileceği ortaya konulmuştur (Tablo 2).

\section{D. $900 \mathrm{MHz} / 1800 \mathrm{MHz}$ veya $800 \mathrm{MHz} / 1900 \mathrm{MHz}$ EMR Maruziyetlerine Ait Literatür Çalışmaları}

Shehu ve arkadaşları (27) çalışmalarında, erkek Wistar Albino sıçanlarda ( $\mathrm{n}=25,180-200$ gr), cep telefonu 900/1800 MHz GSM EMR, zil sesi ve titreşime maruz kalmanın, anksiyete benzeri davranış ve oksidatif stres biyobelirteçleri üzerine etkilerini araştırmışlardır. Bu sıçanlar rastgele olarak her bir grupta beş sıçan olacak şekilde; kapalı konumda cep telefonuna maruz kalan grup I (kontrol), sessiz konumda cep telefonuna maruz kalan grup II (EMR), titreşim modunda cep telefonuna maruz kalan grup III (V: vibration), zil sesi modunda cep telefonuna maruz kalan grup IV (R: ringtone) ve sessiz, titreşim, zil sesi konumlarında maruz kalan grup $\mathrm{V}$ $(\mathrm{EMR}+\mathrm{R}+\mathrm{V})$ olmak üzere toplam beş gruba ayrılmıştır. Çalışmada EMR kaynağı olarak, 900/1800 MHz GSM bant üreten cep telefonu kullanılmıştır. Grup II ve V'deki sıçanlara, cep telefonu aracılığıyla dört hafta boyunca günde toplam 10 dakika süren 30 cevapsız çağrı (her biri 20 saniye) şeklinde EMR maruziyeti uygulanmıştır. Son EMR maruziyetlerinden sonra sıçanların anksiyete benzeri davranışları, EPM testi ile değerlendirilmiştir. Ayrıca biyokimyasal analizler ile sıçanların beyin dokularındaki lipid peroksidasyonu (MDA düzeyleri), antioksidant enzimler (SOD, CAT aktiviteleri), glutatyon peroksidaz (GPx) aktivitesi belirlenmiştir. EPM testi sonuçlarına göre, sıçanların açık kolda kalma süreleri ve keşif aktivitelerinde, kontrol grubuna göre tüm deney gruplarında anlamlı azalmalar saptandığından $(p<0,05)$, EMR maruziyetinin anksiyeteyi arttırdığ 1 gözlenmiştir. Ayrıca kontrol grubu ile karşılaştırıldığında, grup IV $(\mathrm{EMR}+\mathrm{R})$ ve $\mathrm{V} \quad(\mathrm{EMR}+\mathrm{R}+\mathrm{V})$ 'deki sıçanların CAT aktivitelerinde anlamlı bir azalma saptanmıştır $(p<0,05)$. Fakat MDA konsantrasyonu, SOD ve GPx aktiviteleri açısından, kontrol grupları ile diğer deneysel gruplar (grup II, III, IV ve V) arasında istatistiksel açıdan anlamlı bir fark belirlenmemiştir. Sonuç olarak çalışmada, dört haftalık EMR, titreşim, zil sesi veya kombine maruziyetlerin genç Wistar Albino sıçanlarda, anksiyete benzeri davranış ve oksidatif stres üzerinde anlamlı bir etki oluşturduğu ortaya konulmuştur (Tablo 3).

Jadidi ve arkadaşları (28) çalışmalarında, saf dişi $(n=40)$ ve erkek $(n=40)$ farede (25-30 gr), anksiyete düzeyleri üzerinde $900 \mathrm{MHz}$ ve $1800 \mathrm{MHz}$ frekanslarındaki cep telefonu radyasyonun etkilerini 
Tablo 2. 905MHz, 915 MHz, 940 MHz veya 1800 MHz RF/MW-EMR maruziyetlerine ait literatür çalışmaları ve sonuçları

\begin{tabular}{|c|c|c|c|c|c|c|c|c|c|c|}
\hline $\begin{array}{l}\text { Yazar ve Yayın } \\
\text { Yllı } \\
\text { (Kaynak no) }\end{array}$ & $\begin{array}{l}\text { Çalışılan } \\
\text { Frekans } \\
\text { (MHz) }\end{array}$ & $\begin{array}{l}\text { Spesifik } \\
\text { absorbsiyon } \\
\text { oranı } \\
\text { (SAR, W/kg) } \\
\end{array}$ & $\begin{array}{lr}\text { Güç } & \text { yoğunluğu } \\
\text { veya } & \text { elektrik } \\
\text { alan } & \end{array}$ & $\begin{array}{l}\text { Maruziyet } \\
\text { sistemi } \\
\text { kurulumu }\end{array}$ & veya & Maruziyet süresi & $\begin{array}{l}\text { Maruziyet } \\
\text { bölgesi (tüm } \\
\text { vücut/baş/karın } \\
\text { (abdomen)) } \\
\end{array}$ & $\begin{array}{l}\text { Hayvan } \\
\text { modeli (yaş) }\end{array}$ & Çalışılan parametreler & Çalışmanın sonuçları \\
\hline $\begin{array}{l}\text { Khirazova ve } \\
\text { ark. } 2012 \text { (22) }\end{array}$ & $905 \mathrm{MHz}$ & $1,67 \mathrm{~W} / \mathrm{kg}$ & Puls gücü: $2 \mathrm{~W}$ & $\begin{array}{l}\text { GSM } \\
\text { telefonu }\end{array}$ & сер & İki saat & Tüm vücut & $\begin{array}{l}\text { Beyaz } \\
\text { outbred sıçan } \\
(10-12 \\
\text { haftalık })\end{array}$ & $\begin{array}{l}\text { Anksiyete düzeyi, } \\
\text { lokomotor, yönelim ve } \\
\text { keşif aktiviteleri, ADS } \\
\text { parametreleri }\end{array}$ & $\begin{array}{l}\text { RF-EMR maruziyeti, dişi siçanlarda anksiyete'de } \\
\text { artş̧, lokomotor, yönelim ve keşif aktivitelerinde } \\
\text { azalma, erkek siçanlarda, yönelim, anksiyete'de } \\
\text { azalma keşif ve lokomotor aktivitelerinde artma } \\
\text { göstermiştir. Erkek sıçanlarda, gecikmiş dönemde } \\
\text { EMR ile glukokortikoid düzeyleri ve } 20 \text { dakika } \\
\text { sonrası kontrole göre lipid hidroperoksit seviyeleri } \\
\text { azalmışstır. Dişi sıçanlarda, EMR'den sonra } 24 \text { saatte } \\
\text { SOD benzeri plazma aktivitesi artmıștır. }\end{array}$ \\
\hline $\begin{array}{l}\text { Nittby ve ark. } \\
2008 \text { (23) }\end{array}$ & $915 \mathrm{MHz}$ & $\begin{array}{l}0,6 \mathrm{~mW} / \mathrm{kg} \\
60 \mathrm{~mW} / \mathrm{kg}\end{array}$ & $10 \mathrm{~W} / \mathrm{m}^{2}$ & $\begin{array}{l}\text { GSM }-900 \mathrm{I} \\
\text { cep telefonı }\end{array}$ & $\begin{array}{l}\mathrm{MHz} \\
\mathrm{u}\end{array}$ & $\begin{array}{l}55 \text { hafta boyunca } 2 \\
\text { saat/hafta }\end{array}$ & Tüm vücut & $\begin{array}{l}\text { Dişi ve erkek } \\
\text { Fischer 344 } \\
\text { siçanlar (4-6 } \\
\text { aylık) }\end{array}$ & $\begin{array}{ll}\text { Anksiyete, keşif davranışı, } \\
\text { bilisssel } & \text { (kognitif) } \\
\text { davranışlar } & \end{array}$ & 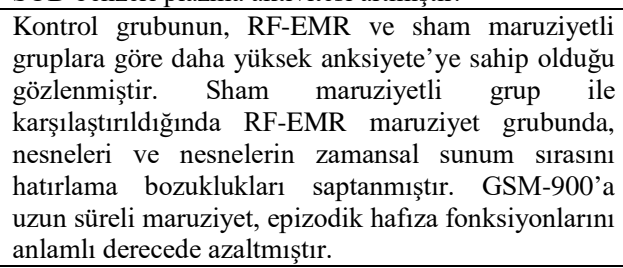 \\
\hline $\begin{array}{l}\text { Ahmadi ve ark. } \\
2015 \text { (24) }\end{array}$ & $940 \mathrm{MHz}$ & Bildirilmemiştir. & Bildirilmemiştir. & Cep telefon & & $\begin{array}{ll}\begin{array}{l}\text { Deney grubu } \\
\text { (1 saat/gün) }\end{array} & 1 \\
\begin{array}{l}\text { Deney grubu } \\
\text { (3 saat/gün) }\end{array} & 2 \\
\begin{array}{l}\text { Deney grubu } \\
\text { (6 saat/gün) }\end{array} & 3\end{array}$ & Tüm vücut & $\begin{array}{l}\text { Erkek Wistar } \\
\text { Albino siçan }\end{array}$ & $\begin{array}{l}\text { Anksiyete düzeyleri, serum } \\
\text { kortizol seviyeleri }\end{array}$ & $\begin{array}{l}\text { EPM testinde, tüm deney gruplarında, kontrol } \\
\text { gruplarına göre, açık kollarda harcanan zaman } \\
\text { yüzdesi ve açık kollara giriş yüzdesi anlamlı derecede } \\
\text { azalması (her biri için } p<0,001) \text { nedeniyle anksiyete } \\
\text { düzeyi artmıştır. RF-EMR maruziyeti deney grubu } \\
\text { 3'deki sıçanların kortizol seviyeleri, kontrol } \\
\text { grubundaki sıçanlara ait değerlere göre anlaml } \\
\text { derecede artmıştır }(\mathrm{p}<0,05) \text {. }\end{array}$ \\
\hline $\begin{array}{l}\text { Zhang ve ark. } \\
2017 \text { (25) }\end{array}$ & $1800 \mathrm{MHz}$ & $\begin{array}{l}2,7 \quad \mathrm{~W} / \mathrm{kg} \quad \text { (tüm } \\
\text { vücut) } \\
2,2 \mathrm{~W} / \mathrm{kg} \text { (baş) }\end{array}$ & $530 \mu \mathrm{W} / \mathrm{cm}^{2}$ & $\begin{array}{l}1800 \\
\text { radyasyon } \\
\text { maruziyet } \\
\text { sistemi }\end{array}$ & $\mathrm{MHz}$ & $\begin{array}{l}28 \text { gün boyunca } 6 \\
\text { saat/gün }\end{array}$ & Tüm vücut & $\begin{array}{l}\text { Erkek } \\
\text { C57BL/6 fare } \\
\text { (4 haftalık) }\end{array}$ & $\begin{array}{l}\text { Anksiyete, depresyon } \\
\text { benzeri davranış, uzaysal } \\
\text { öğrenme, hafiza, aminoasit } \\
\text { nörotransmitter düzeyleri } \\
\text { ve beyin histolojisi }\end{array}$ & $\begin{array}{l}\text { RF-EMR maruziyeti ile anksiyete benzeri } \\
\text { davranışlarda artma, korteks ve hipokampüs'teki } \\
\text { GABA ve Asp düzeylerinde azalma saptanmışstır. } \\
\text { Depresyon benzeri davranışlar, uzaysal hafiza ve } \\
\text { beyin histolojisinde RF-EMR maruziyeti ile herhangi } \\
\text { bir değişiklik gözlenmemiştir. }\end{array}$ \\
\hline $\begin{array}{l}\text { Júnior ve ark. } \\
2014 \text { (26) }\end{array}$ & $1800 \mathrm{MHz}$ & Bildirilmemiştir. & $\begin{array}{l}\text { Ortalama elektrik } \\
\text { alan şiddeti } 2,0 \\
\text { V/m }\end{array}$ & $\begin{array}{l}\text { GSM } \\
\text { telefonu }\end{array}$ & сер & $\begin{array}{l}\text { Üç gün boyunca, iki } \\
\text { dakika da bir } 25 \\
\text { saniye süreli cep } \\
\text { telefonu çağrıları }\end{array}$ & Tüm vücut & $\begin{array}{l}\text { Erkek Wistar } \\
\text { Albino siçan } \\
\text { (60 günlük) }\end{array}$ & $\begin{array}{l}\text { Anksiyete, stres profilleri, } \\
\text { lokomotor aktivite, WM } \\
\text { çalışma belleği }\end{array}$ & $\begin{array}{l}\text { RF-EMR maruziyetinin, anksiyete ve çalışma belleği } \\
\text { bozukluğuna neden olmaz iken, stresli davranış } \\
\text { yapılarına neden olabileceği ortaya konulmuştur. }\end{array}$ \\
\hline
\end{tabular}

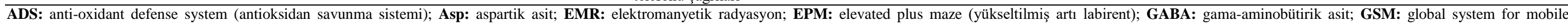
communications (mobil iletişim için küresel sistem); RF-EMR: radyofrekans elektromanyetik radyasyon; SAR: specific absorbation rate (spesifik absorbiyon oranı); SOD: süperoksit dismutaz 
Tablo 3. 900MHz/1800 MHz, 800 MHz/1900 MHz, 900 MHZ/1800 MHz/2100 MHz veya 900 MHZ/1800 MHz/2450 MHz RF/MW-EMR maruziyetlerine ait literatür çalışmaları ve sonuçları

\begin{tabular}{|c|c|c|c|c|c|c|c|c|c|}
\hline $\begin{array}{l}\text { Shehu ve ark. } \\
2016 \text { (27) }\end{array}$ & $\begin{array}{l}900 \mathrm{MHz} \\
1800 \mathrm{MHz}\end{array}$ & Bildirilmemiştir. & Bildirilmemiştir. & $\begin{array}{lr}900 / 1800 & \mathrm{MHz} \\
\mathrm{GSM} & \text { bant } \\
\text { üreten } & \text { cep } \\
\text { telefonu } & \end{array}$ & $\begin{array}{l}\text { hafta boyunca } \\
\text { günde } 10 \text { dakika } \\
\text { süren } 30 \text { cevapsiz } \\
\text { çağrı (her biri } 20 \\
\text { saniye) }\end{array}$ & Tüm vücut & $\begin{array}{l}\text { Erkek Wistar } \\
\text { Albino siçan }\end{array}$ & $\begin{array}{l}\text { Anksiyete } \quad \text { benzeri } \\
\text { davranış ve oksidatif } \\
\text { stres biyobelirteçleri }\end{array}$ & $\begin{array}{l}\text { EMR maruziyeti, anksiyetede artma ve CAT } \\
\text { aktivitesinde azalmaya neden olmuştur ( }<<0,05 \text { ). } \\
\text { Maruziyet sonucu, MDA konsantrasyonu, SOD ve } \\
\text { GPx aktivitelerinde istatistiksel olarak anlamlı bir } \\
\text { değişme gözlenmemiştir. }\end{array}$ \\
\hline $\begin{array}{l}\text { Jadidi ve ark. } \\
2014 \text { (28) }\end{array}$ & $\begin{array}{l}900 \mathrm{MHz} \\
1800 \mathrm{MHz}\end{array}$ & Bildirilmemiştir. & Bildirilmemiştir. & $\begin{array}{l}\text { Cep telefonuna } \\
\text { parazit yapan } \\
\text { baz istasyonu }\end{array}$ & 2 saat & Tüm vücut & $\begin{array}{l}\text { Saf dişi } v e \\
\text { erkek fare }\end{array}$ & $\begin{array}{ll}\text { Anksiyete } & \text { benzeri } \\
\text { davranışlar } & \end{array}$ & $\begin{array}{l}\text { Erkek farelerde } 900 \mathrm{MHz} \text { RF-EMR ve dişi farelerde } \\
900 \mathrm{MHz}+1800 \mathrm{MHz} \text { RF-EMR maruziyeti, } \\
\text { anksiyete düzeylerini arttırmıştır. }\end{array}$ \\
\hline $\begin{array}{l}\text { Kumar ve } \\
\text { ark. } 2009 \\
\text { (29) }\end{array}$ & $\begin{array}{l}900 \mathrm{MHz}, \\
1800 \mathrm{MHz}\end{array}$ & Bildirilmemiştir. & Bildirilmemiştir. & $\begin{array}{l}\text { GSM } \\
\text { telefonu }\end{array}$ & $\begin{array}{l}4 \text { hafta boyunca } 50 \\
\text { cevapsız çağrı (her } \\
\text { bir cevapsız çağr1 } \\
\begin{array}{lll}\text { aras1 } & 15 & \text { saniye)/ } \\
\text { gün } & \end{array}\end{array}$ & Tüm vücut & $\begin{array}{l}\text { Erkek Wistar } \\
\text { Albino slçan } \\
\text { (10-12 haftalık) }\end{array}$ & Anksiyete & $\begin{array}{l}\text { EPM testinde açik kol keşfinde bozulma } \\
\text { sergileyerek, cep telefonu radyasyon maruziyeti } \\
\text { anksiyete de artşsa neden olmuştur. }\end{array}$ \\
\hline $\begin{array}{l}\text { Aldad ve ark. } \\
2012 \text { (30) }\end{array}$ & $\begin{array}{l}800 \mathrm{MHz} \\
1900 \mathrm{MHz}\end{array}$ & $1,6 \mathrm{~W} / \mathrm{kg}$ & Bildirilmemiştir. & Cep telefonu & $\begin{array}{l}\text { Gebelik boyunca } 24 \\
\text { saat/gün için telefon } \\
\text { aktif arama } \\
\text { modunda }\end{array}$ & Tüm vücut & $\begin{array}{l}\text { CD-1 erkek ve } \\
\text { dişi fareler }\end{array}$ & $\begin{array}{l}\text { Bellek, anksiyete ve } \\
\text { hiperaktivite. } \\
\text { Kortikosteron seviyesi, } \\
\text { prefrontal, ventral } \\
\text { medial hipotalamusta } \\
\text { mEPSC'lar }\end{array}$ & $\begin{array}{l}\text { Rahim içi (in utero) RF'a maruz kalan farelerin } \\
\text { hiperaktif olduğu, bu maruziyetin hafiza ve } \\
\text { anksiyeteyi azalttığ saptanmıştır. RF maruziyeti } \\
\text { uygulanan farelerde, prefrontal korteksin V. katmant } \\
\text { piramidal nöronları glutamaterjik sinaptik iletiminde } \\
\text { RF dozuna bağl nörogelişimsel bozukluklar } \\
\text { belirlenmiştir. }\end{array}$ \\
\hline $\begin{array}{l}\text { Esmaili ve } \\
\text { ark. } 2017 \\
\text { (31) }\end{array}$ & $\begin{array}{l}900 \mathrm{MHz} \\
1800 \mathrm{MHz} \\
2100 \mathrm{MHz}\end{array}$ & $\begin{array}{l}1,44 \mathrm{~W} / \mathrm{kg} \\
\text { (tüm vücut) } \\
1,30 \mathrm{~W} / \mathrm{kg} \text { (baş) }\end{array}$ & Bildirilmemiştir. & Cep telefonu & 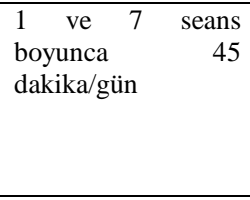 & $\begin{array}{l}\text { Tüm vücut, } \\
\text { baş bölgesi }\end{array}$ & Erkek saf sıçan & $\begin{array}{lr}\text { Anksiyete } & \text { benzeri } \\
\text { davranış, SOD düzeyleri }\end{array}$ & $\begin{array}{l}\text { Sıçanların anksiyete benzeri davranışlarında akut } \\
\text { cep telefonu radyasyonu maruziyetinin herhangi bir } \\
\text { etkisi saptanmamıştır. Ayrıca SOD düzeyleri } \\
\text { açısından, } 45 \text { dakikalık tek seans ve bir haftalık akut } \\
\text { radyasyon maruziyetinden sonra gruplar arasında } \\
\text { anlamlı farklılıklar gözlenmemiştir. }\end{array}$ \\
\hline $\begin{array}{l}\text { Gupta ve ark. } \\
2019 \text { (32) }\end{array}$ & $\begin{array}{l}900 \mathrm{MHz} \\
1800 \mathrm{MHz} \\
2450 \mathrm{MHz}\end{array}$ & $\begin{array}{l}0,042 \mathrm{~W} / \mathrm{kg} \\
\text { (tüm vücut) } \\
0,131 \mathrm{~W} / \mathrm{kg} \text { (baş) }\end{array}$ & $0,1227 \mathrm{~W} / \mathrm{m}^{2}$ & $\begin{array}{lr}100 & \mathrm{kHz}-20 \\
\mathrm{GHz} & \text { frekans } \\
\text { aralığına } & \text { sahip } \\
\text { anolog } & \text { sinyal } \\
\text { üreten } & \text { EMA } \\
\text { jenaratör } & \end{array}$ & $\begin{array}{l}28 \text { gün boyunca } 1 \\
\text { saat/gün }\end{array}$ & $\begin{array}{l}\text { Tüm vücut, } \\
\text { baş bölgesi }\end{array}$ & $\begin{array}{l}\text { Erkek } \\
\text { Foster Albinos- } \\
\text { siçan }\end{array}$ & $\begin{array}{lr}\text { Anksiyete } & \text { benzeri } \\
\text { davranıs, kortikosteron, } \\
\text { CRH-2, GR, } \\
\text { mitokondri } \\
\text { fonksiyon/bütünlük, } \\
\text { mitokondriyal Bax, Bcl- } \\
\text { 2, GR ve CRH-2, } \\
\text { sitoplazmik Bax, } \\
\begin{array}{l}\text { sitokrom-C, kaspaz-3 } \\
\text { miktarlarl, SOD, CAT } \\
\text { aktiviteleri }\end{array}\end{array}$ & $\begin{array}{l}\text { Uzun süreli EMR-2450 MHz maruziyet, amigdalada } \\
\text { CRH-2 ve GR ekspresyonununda anlamll azalmalar } \\
\text { ve kortikosteron düzeylerinde artş ile birlikte } \\
\text { anksiyete benzeri davranışları gelişimine neden } \\
\text { olmuştur. Fakat EMR-900 MHz ve EMR-1800 MHz } \\
\text { maruziyetlerin anksiyete benzeri davranışlar } \\
\text { üzerinde herhangi bir etkisi bulunmamıştır. Ayrıca } \\
\text { EMR-2450 MHz maruziyet, MMP seviyelerinde ve } \\
\text { amigdalar nöronal hücrelerde azalmalar, sitoplazmik } \\
\text { ve mitokondrial Bcl2 ve Bax protein } \\
\text { ekspresyonlarında değişimlere neden olmuştur. }\end{array}$ \\
\hline
\end{tabular}

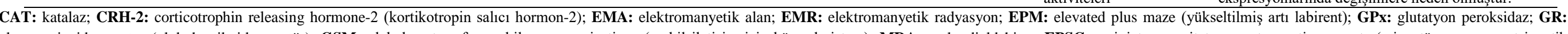

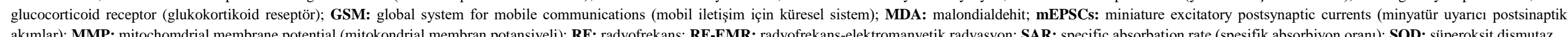


araştırmışlardır. Çalışmadaki fareler, rastgele olacak şekilde kontrol, $900 \mathrm{MHz}, 1800 \mathrm{MHz}$ ve $900+1800 \mathrm{MHz}$ maruziyetler olmak üzere toplam dört gruba ayrılmıştır. $\mathrm{Bu}$ fareler, belirlenen frekans şiddetlerinde iki saat boyunca cep telefonu radyasyonuna maruz bırakılmıştır. Daha sonra anksiyete benzeri davranışlar, EPM testi ve aydınlık/karanlık (L/D: light and dark) kutu deneyi ile analiz edilmiştir. Çalışma bulgularında, $900 \mathrm{MHz}$ cep telefonuna parazit yapan maruziyetin, kontrol grubuna göre erkek farelerde, L/D kutusunun aydınlatılmış kısmında harcanan zamanı kısalttığı gözlenmiştir. Kontrol grubuna göre, hem dişi hem de erkek farelerde $1800 \mathrm{MHz}$ radyasyon maruziyetinde, L/D kutusunun aydınlatılmış kısmında ve EPM açık kolunda harcanan zaman artmıştır $(p=0,05)$. Ayrıca dişi farelerde 900+1800 $\mathrm{MHz}$ radyasyon maruziyetinde, L/D kutusunun karanlık kısmında harcanan zaman artmıştır. Sonuç olarak çalışmada, erkek ve dişi farelerde sırasıyla $900 \mathrm{MHz}$ ve $900 \mathrm{MHz}+1800 \mathrm{MHz}$ cep telefonu radyasyon maruziyetlerinin, anksiyete düzeylerini arttırdığ 1 ortaya konulmuştur (Tablo 3).

Kumar ve arkadaşları (29) çalışmalarında, erkek Wistar Albino sıçanlarda ( $\mathrm{n}=12,10-12$ haftalık), $900 \mathrm{MHz} / 1800$ $\mathrm{MHz}$ GSM cep telefonu maruziyetinin davranışsal değişiklikler üzerindeki etkilerini EPM testi aracığıyla araştırmışlardır. $\mathrm{Bu}$ sıçanlar, her bir grupta altı sıçan olacak şekilde radyasyon maruziyetine uğramayan grup I (kontrol) ve dört hafta boyunca $900 \mathrm{MHz} / 1800 \mathrm{MHz}$ GSM cep telefonu titreşim modunda iken (zil sesi kapalı), günde 50 cevapsız çağrıya (her bir cevapsız çağrı arası 15 saniye aralığında) maruz birakılan grup II olarak toplam iki gruba ayrılmıştır. Ayrıca çalışmada, her bir cevapsız çağrı bir dakika sürmüştür. Deney aşamasından sonra tüm sıçanlara EPM testi uygulanmıştır. EPM testinde, önceki deneyimler hayvan davranışlarını değiştireceğinden, sıçanların iki kez maruz bırakılamayacağı bilinerek deney protokolü uygulanmıştır. $\mathrm{Bu}$ nedenle çalışmada, cep telefonuna maruz birakılan sıçanların üçü son maruziyetten bir saat sonra teste tabi tutulur iken, diğer üç sıçan maruziyetten 24 saat sonra teste tabi tutulmuştur. EPM testinde, açık kolların keşfinde azalma ve son radyasyon maruziyetinden 24 saat sonra bile bu azalmanın devam etmesi bulgularından hareketle, cep telefonuna maruziyetin sıçanların davranışlarını değiştirdiği sonucuna varılmıştır. Açık kollarda harcanan süre parametresinde de kontrol grubuna göre, cep telefonu maruziyetinden 24 saat ve bir saat sonra test edilen sıçanlarda, sırasıyla yaklaşık olarak üç ve altı kat azalma saptanmıştır. Ayrıca EPM testi boyunca, korkunun belirtisi olan defekasyon pelletleri, cep telefonuna maruz kalan sıçanlarda gözlenir iken, kontrol grubu sıçanların kafeslerinde belirlenmemiştir. Sonuç olarak çalışmada, cep telefonu maruziyetinin, EPM testi ile sıçanların açık kol keşfinde bozukluklara neden olarak davranışsal değişikliklere, başka bir deyişle anksiyetede artışa neden olduğu ortaya konulmuştur (Tablo 3).

RF radyasyon maruziyetinin nörogelişimsel süreç üzerindeki direkt etkilerini açıklığa kavuşturabilmek amacı ile Aldad ve arkadaşları (30) çalışmalarında, yetişkin CD-1 erkek ve dişi farelerin rahim içi (in utero) bölgelerine cep telefonlarından $\mathrm{RF}$ radyasyonun uygulandığ 1 bir fare modeli oluşturmuşlardır. Daha sonra, fetal RF maruziyeti sonucu, anksiyeteyi belirlemek için fareler 12., 15. ve 18. haftalık iken L/D kutu deneyi ile karanlıkta geçirilen zaman ölçülmüş, rahim içi (in utero) RF'a maruz kalan deneysel gruptaki farelerin $(n=13)$ karanlıkta ortalama 270 saniye harcadıkları belirlenir iken, kontrol grubu farelerin $(n=14)$ ise karanlıkta ortalama 234 saniye harcadıkları saptanmıştır. Bu sonuç, farelerde cep telefonu 800/1900 $\mathrm{MHz}$ GSM RF maruziyetinin anksiyete'yi anlamlı derecede azalttığını göstermiştir ( $\mathrm{p}<0,001)$. Ayrıca rahim içi (in utero) RF'a maruz kalan farelerde hiperakitivite ve nesne tanımada, L/D kutu ve step-down (düşürme) deneyleri ile farelerin hafızalarında zayıflama olduğu da belirlenmiştir. Ek olarak çalışmada, minyatür uyarıcı postsinaptik akımların (mEPSCs: miniature excitatory postsynaptic currents) tüm hücre patch (kenetleme) kayıtları, bu davranışsal değişikliklerin, nöronal gelişim programlamadaki değişikliklerden kaynaklandığını ortaya koymuştur. Çünkü RF maruziyetine uğramış farelerde, prefrontal korteksin V. katmanı piramidal nöronların glutamaterjik sinaptik iletiminde RF dozuna bağlı bozulmalar belirlenmiştir. Sonuç olarak çalışmada, farelerde 800 $\mathrm{MHz} / 1900 \mathrm{MHz}$ derecelerine sahip cep telefonlarından yayılan fetal RF radyasyon maruziyetinin (gestasyon boyunca 24 saat/gün), nöron gelişimi ve sonraki davranışlarını etkileyerek, nörogelişimsel bozukluklara yol açtığı gösterilmiştir (Tablo 3).

\section{E. $900 \mathrm{MHz} / 1800 \mathrm{MHz} / 2100 \mathrm{MHz}$ veya $900 \mathrm{MHz} / 1800$} MHz/2450 MHz EMR Maruziyetlerine Ait Literatür Çalışmaları

Esmaili ve arkadaşları (31) çalışmalarında, üç farklı frekans değerlerindeki (900 MHz, $1800 \mathrm{MHz}, 2100$ $\mathrm{MHz}$ ) cep telefonu radyasyon maruziyetinin erkek sıçanların anksiyete benzeri davranışlar ve SOD düzeyleri üzerindeki etkilerini belirlemeyi amaçlamışlardır. Çalışmadaki sıçanlar $(n=80)$, rastgele seçilerek her bir grupta bir ve yedi seans uygulanacak şekilde cep telefonu maruziyeti olmayan sham kontrol ve $900 \mathrm{MHz}, 1800$ $\mathrm{MHz}$ ve $2100 \mathrm{MHz}$ radyasyon maruziyet grupları olmak üzere toplam sekiz gruba ayrılmıştır. Anksiyete davranışı üzerine cep telefonu radyasyonunun akut ve kronik etkileri, 45 dakikalı bir seans ve yedi seans (45 dakika/gün) maruziyeteler sonrası EPM testleri ile karşılaştırılmıştır. Bu testte anksiyete düzeyleri, açık ve kapalı kollardan giren sıçan sayıları ve kolların her birinde kalma süreleri ile belirlenmiştir. Ayrıca oksidatif stresi değerlendirmek için, sıçanların kan serumlarındaki SOD düzeyleri ölçülmüştür. EPM testinden elde edilen sonuçlarda, sıçanlarda cep telefonu radyasyonuna hem 45 dakikalık tek seans akut hem de 45 dakikalık yedi seans kronik maruziyetlerden sonra, anksiyete düzeylerini belirleyen, sıçanların açık kola giriş sayısı, açık ve kapalı kollara toplam giriş sayıları, açık ve kapalı kollarda kalma süreleri bakımından gruplar arasında anlamlı farklılıklar saptanmamıştır (her biri için $p>0,05$ ). Ayrıca SOD düzeyleri bakımından da, cep telefonu radyasyonunun 45 dakikalık tek seans ve yedi seans maruziyetlerinden sonra gruplar arasinda anlaml farklılıklar gözlenmemesine rağmen $(\mathrm{p}>0,05)$, diğer gruplar ile karşılaştırıldığında $900 \mathrm{MHz}$ frekans maruziyete uğrayan sıçanların SOD değerleri daha düşük bulunmuştur. Sonuç olarak çalışmada, cep telefonu ile uygulanan akut radyasyonun (900 MHz, $1800 \mathrm{MHz}, 2100$ $\mathrm{MHz}$, EPM testinde erkek sıçanların anksiyete benzeri 
davranışları üzerinde herhangi bir etkisi gözlenmemiştir (Tablo 3).

Gupta ve arkadaşları (32) çalışmalarında, erkek CharlesFoster Albino siçanlarda ( $\mathrm{n}=24,180 \pm 20$ gr $)$, farklı frekanslardaki (900 MHz, $1800 \mathrm{MHz}, 2450 \mathrm{MHz}$ ) EMR maruziyetlerinin, anksiyete benzeri davranış üzerindeki etkilerini araştırmayı amaçlamışlardır. $\mathrm{Bu}$ sıçanlar, rastgele seçilerek her bir grupta altı sıçan olacak şekilde; kontrol, EMR-900 MHz, EMR-1800 MHz ve EMR-2450 $\mathrm{MHz}$ olarak toplam dört gruba ayrılmıştır. EMR-900 $\mathrm{MHz} / 1800 \mathrm{MHz} / \mathrm{EMR}-2450 \mathrm{MHz}$ gruplarına, $100 \mathrm{kHz}-$ $20 \mathrm{GHz}$ frekans aralığına sahip anolog sinyal üreten EMA jenaratör ile 28 gün boyunca günde bir saat olacak şekilde EMR maruziyeti uygulanmıştır. Siçanların anksiyete benzeri davranışları, EPM, OF testleri ve delik tahta testi (HBT: hole-board test) ile belirlenmiştir. Ayrıca çalışmada stres yanıtının göstergesi olarak, plazma kortikosteron ve amigdaladaki kortikotropin salıcı hormon-2 (CRH-2: corticotrophin releasing hormone-2) ve glukokortikoid reseptör (GR: glucocorticoid receptor) ekspresyon düzeyleri, mitokondrial membran potansiyeli (MMP: mitochomdrial membrane potential) ile mitokondri fonksiyon ve bütünlüğü, Western blot analizi ile mitokondriyal Bax, Bcl-2, GR ve CRH-2 ile sitoplazmik Bax, sitokrom-C, kaspaz-3 miktarları, SOD ve CAT aktiviteleri ve histopatolojik incelemeler ile amigdaladaki nöronal hücreler değerlendirilmiştir. EMR2450 MHz'e maruz kalan sıçanların OF testlerinde, hayvanlar ambulasyon, şahlanma (rearing) ve süslenme (grooming) davranışlarında azalma yönüyle anksiyojenik davranışlar sergilediğinden, EMR-2450 MHz'a uzun süreli maruziyetin anksiyete benzeri davranışların gelişimine neden olduğu saptanmıştır. Ayrıca sürekli EMR-2450 MHz'a maruziyeti ile, siçanların OF testindeki merkez kare bölgeye geçişinde de azalma gözlenmiştir. Fakat EMR-900 MHz ve EMR-1800 MHz'e maruz kalan sıçanların bu davranışları üzerinde radyasyonun herhangi bir etkisi gözlenmemiştir. Ayrıca EMR-2450 MHz maruziyeti, plazma kortikosteron düzeylerindeki artış ile strese neden olur iken, amigdaladaki CRH-2 ve GR ekspresyonlarında anlaml derecede azalmalar oluşturmuştur. Ek olarak, kronik EMR-2450 MHz'a maruziyet, MMP seviyelerinde anlamlı azalmalar ortaya koyarken, EMR-900 $\mathrm{MHz}$ ve EMR-1800 MHz'e maruziyette MMP seviyelerinde herhangi bir değişim belirlenmemesine bağlı olarak, EMR-2450 maruziyetinin, mitokondriyal fonksiyon ve bütünlüğünü bozduğu sonucuna varılmıştır. Bununla birlikte, EMR-2450 MHz'a maruziyet sonucu, mitokondride $\mathrm{Bcl} 2 \quad$ (anti-apoptotik protein) ekspresyonunda anlamlı bir azalma ile Bax (proapoptotik protein) ve $\mathrm{Bax} / \mathrm{Bcl} 2$ oranında artma gözlenirken, sitoplazmada değişen apoptozis regülasyonunu ifade eden tersi değişimler meydana gelmiştir. Ayrıca EMR-2450 MHz maruziyeti, sitokrom-c salınımına ve apoptotik hücre ölümünün aktivasyonuna neden olan kaspaz 9 ekspresyonuna neden olmuştur. Bu frekanstaki (2450 MHz) EMR maruziyetinden sonra, nekrotik ve apoptotik amigdalar hücre ölümü belirlenmiştir. Histopatolojik bulgular ise, EMR-2450 $\mathrm{MHz}$ maruziyetinin, amigdaladaki nöronal hücrelerde anlamlı azalmalara neden olduğunu da göstermiştir. Sonuç olarak çalışmada, uzun süreli EMR-2450 MHz maruziyetin, bir stres faktörü olarak rol oynadığını ve sıçanlarda patofizyolojik değişiklikler ile birlikte anksiyete benzeri davranışlara neden olduğu ortaya konulmuştur (Tablo 3).

\section{F. $2100 \mathrm{MHz}, 2450 \mathrm{MHz}, 2500 \mathrm{MHz}$ veya $9417 \mathrm{MHz}$ EMR maruziyetlerine ait literatür çalışmaları}

Sharma ve arkadaşları (33) çalışmalarında, radyasyon ile ilişkili bilişsel (kognitif) bozukların altında yatan mekanizmaları belirleyebilmek için, erkek Wistar Albino

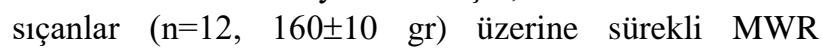
maruziyetinin anksiyete, uzaysal çalışma belleği (WM: working memory), nöromuskular fonskiyon ve oksidatif savunma sistemi parametreleri üzerindeki etkilerini araştırmışlardır. Sıçanlar, MWR maruziyetine uğramayan kontrol ( $n=6)$ ve üç ay (90 gün) boyunca, haftada beş gün ve günde dört saat olacak şekilde $2100 \mathrm{MHz}$ MWR maruziyetine uğrayan deney grubu $(n=6)$ olacak şekilde toplam iki gruba ayrılmıştır. Üç ay MWR maruziyeti sonrası, EPM testi ile sıçanlarda anksiyete, stres ve korku ile ilişkili davranışlar değerlendirilmiştir. EPM testinde, sıçanlarda anksiyete seviyelerini belirlemek için sıçanların açık ve kapalı kollara giriş sayıları ölçülmüştür. Diğer davranışsal testlerden; T-labirent (T-maze) testi ile uzaysal WM ve kavrama kuvveti testi ile de nöromuskular fonksiyonlar incelenmiştir. T- labirent testinde, uzaysal öğrenme ve hafizayı değerlendirmek için test süresi ve yol etkinliği belirlenmiştir. Ayrıca lipid peroksidasyonu (LPO), redükte glutatyon (GSH), SOD ve CAT, asetil kolinesteraz (AChE) biyokimyasal parametreleri ölçülmüş ve beyin dokusu (hipokampüs) histopatolojik olarak da incelenmiştir. EPM testi bulgularında, kontrol grubuna göre MWR maruziyetinin, açık kola giriş sayısında anlamlı azalma $(\mathrm{p} \leq 0,001)$ gösterdiği, dolayısıyla anksiyolitik sıçanların açık koldan kaçınarak, yakın ve güvenli bir yerde kalmayı tercih ettikleri belirlenmiştir. T-labirent testinde, anlamlı derecede test gecikmesinde artma ve yol etkinliğinde azalmaya bağlı olarak uzaysal WM'de değişiklikler ortaya çıkmıştır $(\mathrm{p} \leq 0,001)$. Test sonuçları, MWR maruziyetin hafiza kaybına neden olduğunu ve kontrol grubuna göre MWR'a maruz kalan sıçanların kavrama gücünün anlamlı derecede azaldığını ortaya koymuştur $(\mathrm{p} \leq 0,001)$. Biyokimyasal analiz sonuçlarında, kontrol grubu ile karşılaştırıldığında, deney grubunda MWR maruziyeti ile, GSH içeriğinde anlamlı bir azalma, membran LPO'nunda anlamlı artış saptanmıştır. Ayrıca kronik MWR maruziyetinden sonra, kontrol grubuna kiyasla deney grubunda, SOD, CAT, AChE aktivitelerinde anlamlı azalmalar $(\mathrm{p} \leq 0,001)$ gözlenmiştir. Histopatolojik incelemeler MWR maruziyetinin, beyin dokusunda vakuolizasyon, piknoz, perivasküler boşluklarda artış, demiyelinizasyon ve sinir liflerinde azalma şeklinde nöral dejenerasyona neden olduğunu göstermiştir. Sonuç olarak çalışmada, MWR maruziyetinin toksik etkilerinin, bilişsel (kognitif) ve davranışsal anormalliklere neden olarak intrasellüler oksidatif stres artışı ve nöron dejenerasyonuna yol açtığ için MSS'ni önemli ölçüde bozarak ciddi hastalıklara neden olabileceği sonucuna varılmıştır (Tablo 4).

Varghese ve arkadaşları (6) çalışmalarında, dişi SpragueDawley sıçanlarda ( $\mathrm{n}=12,180-220$ gr), $2450 \mathrm{MHz}$ iyonize olmayan (NI: non ionizing) radyasyon maruziyetinin, davranış, oksidatif stres parametreleri ve 
kaspaz 3 gen ekspresyonu üzerindeki etkilerini değerlendirmişlerdir. Çalışmadaki sıçanlar, NI-EMR'a maruz kalmayan sham maruziyet grubu olan grup $1(n=6)$ ve 2450 MHz NI-EMR'a 45 gün boyunca günde dört saat maruz kalan grup $2(n=6)$ olarak iki gruba ayrılmıştır. Anksiyete, öğrenme ve hafızanın davranışsal testleri olarak; EPM testi, L/D kutu deneyi, yeni nesne tanıma görevi (NORT: new object recognation task) ve MWM testleri deneyin 38. gününde uygulanmaya başlanılmıştır. Oksidatif stres parametreleri ise 45. günde sıçanlar sakrifiye edildikten sonra beyin homojenatlarından ölçülmüştür. NI-EMR'a maruz kalan sıçanların L/D, EPM ve MWM davranış testlerinde anlamlı değişikler saptanmış olup, $2450 \mathrm{MHz}$ NI-EMR maruziyeti, öğrenme ve hafıza performansında azalma (bilişsel (kognitif) düşüş) ve anksiyete benzeri davranışlara neden olmuştur. Ayrıca NI-EMR maruziyeti sıçan beyinlerindeki GSH seviyelerinde belirgin ve CAT, SOD aktivitelerinde anlamlı azalmalar ile birlikte MDA seviyelerinde belirgin bir artışa neden olmuştur. Histopatolojik incelemelerde, gruplar arasinda (sham ve $2450 \mathrm{MHz}$ EMR maruziyet gruplar1) tümör nekrozis faktör alfa (TNF- $\alpha)$ düzeylerinde anlamlı farklılık gözlenmediği için, $2450 \mathrm{MHz}$ NIEMR'nun beyinde inflamatuar değişikliklere neden olmadığ1 sonucuna varılmıştır. Ancak çalışmada, 2450 $\mathrm{MHz}$ NI-EMR güvenliğinin, kronik çalışmalar ile kanıtlanmasına ihtiyaç duyulduğu da ileri sürülmüştür. Ek olarak, sham maruziyet grubuna göre $2450 \mathrm{MHz}$ NIEMR maruziyetine uğrayan siçanların kaspaz 3 gen ekspresyonunda artış (upregulasyon) belirlendiğinden, bu şiddetteki NI-EMR maruziyetin, beyindeki apoptotik mekanizmayı bozabileceği ifade edilmiştir. Nöronların dendritik arborizasyon (tomurcuklanma) analiz bulgularında ise, $2450 \mathrm{MHz}$ NI-EMR maruz kalan sıçanların beyinlerinde nöronal sinyalizasyonu etkileyen dendritik kavşakların ve dallanma noktalarının sayıları, sham maruziyet grubu sıçanlarınkilere göre anlamlı derecede azalmıştır. Sonuç olarak çalışmada, $2450 \mathrm{MHz}$ MWR'a maruziyetinin, sıçanların beyin antioksidan enzim sistemlerinde çöküş ile birlikte, öğrenme ve hafızanın azalması ve anksiyete davranışlarının oluşumuna neden olması sonucu, beyinde zararlı etkilere yol açtığı gösterilmiştir (Tablo 4).

Othman ve arkadaşları (34) çalışmalarında, maternal kısitlayıc1 stres ve/veya $2450 \mathrm{MHz}$ WiFi sinyal maruziyetlerinin, sıçan yavrularının doğum sonrası (postnatal) gelişim ve davranışları üzerindeki etkilerini araştırmışlardır. Çalışmada, gebe Wistar Albino sıçanlar $(\mathrm{n}=24,230-250$ gr) rastgele olarak kontrol, WiFi maruziyet, kısıtlanmış gruplar ile hem kısıtlanmış hem de WiFi maruziyete uğramış kombine grup olmak üzere toplam dört deney grubuna ayrılmıştır. Kontrol grubundaki anne siçanlar, deney dönemi boyunca kafeslerinde bulundurularak mümkün olduğunca WiFi kaynakları ve çevresel stres faktörlerinden (gürültü vb) uzak tutulmuşlardır. Kısıtlayıcı stres ve WiFi maruziyet gruplarının her birine ise, gebelik süresinden doğuma kadar günde iki saat stres ve/veya WiFi maruziyeti uygulanmıştır. Doğum ile birlikte yavruların fiziksel gelişimleri ve nöromotor olgunlaşma verileri değerlendirilmiştir. Ayrıca sıçanlara, doğum sonrası (postnatal) 28., 30. ve 31. günlerde sırasıyla EPM testi, OF aktiviteleri, durağan ışın testi (SPT: stationary beam test) uygulanmıştır. Çalışma bulgularında, tüm deney gruplarında sıçanların gebelik süreci gelişimleri ve doğum sonrası sonuçları üzerinde kısıtlayıcı stres ve/veya WiFi maruziyetinin herhangi bir zararlı etkisi gözlenmemiştir. Fakat daha sonraki dönemde, cinsiyetler arası küçük farklılıklar gösterecek şekilde, yavruların fiziksel gelişimini, kısıtlayıcı stres ve/veya WiFi maruziyetinin değiştirdiği saptanmıştır. Çünkü tek başına WiFi maruziyetinin, yavrulama başına dişi yavruların ortalama sayısını düşürdüğü belirlenmiştir. Ayrıca çalışmada, gebelik süreci boyunca WiFi maruziyeti ve kısıtlamanın ayrı ayrı olarak veya özellikle kombine halde uygulanmasının, çocuk yaştaki sıçanların (özellikle erkek yavrularda), fiziksel ve nöromotor olgunlaşmalarını değiştirdiği, bu maruziyetlerin yetişkin erkek ve dişi sıçanlarda anksiyete benzeri davranış, motor eksikliği, keşif davranışı bozukluğuna neden olduğu da ortaya konulmuştur. Biyokimyasal sonuçlar, her üç uygulamanın (WiFi maruziyet, kısıtlanmış ve hem kısıtlanmış hem de WiFi maruziyete uğramış gruplar) her iki cinsiyetteki yavruların beyinlerindeki oksidatif stres yanıtlarının oluşumuna (MDA seviyeleri, SOD ve CAT aktiviteleri, thiol (-SH) grup konsantrasyonlarında artış1 indükleyerek) neden olduğunu göstermiştir. Serumdaki biyokimyasal sonuçlara göre, stres kısitlama ve/veya WiFi maruziyet uygulamalarının, fosfor, magnezyum, glikoz, trigliseritler ve kalsiyum düzeylerini bozduğu da saptanmıştır. Sonuç olarak, çalışmada doğum öncesi (prenatal) $2450 \mathrm{MHz} \mathrm{WiFi}$ radyasyon ve/veya kısıtlama maruziyetinin, sıçan yavrularının cinsiyetine bağımlı farklı etkiler oluşturarak, sıçanların çocukluk ve erişkin yaşlarında bazı davranışsal ve biyokimyasal bozukluklara neden olduğu gösterilmiştir (Tablo 4).

Othman ve arkadaşları (35) tarafindan gerçekleştirilen diğer bir çalışmada ise, önceki çalışma (34) amaçlarına benzer şekilde, doğum öncesi (prenatal) $2450 \mathrm{MHz}$ WiFi RF maruziyetin, sıçan yavrularının postnatal gelişim ve davranışı üzerindeki etkileri araştırılmıştır. Çalışmada, gebe Wistar Albino siçanlar $(n=10)$ rastgele olarak, her bir grupta beş sıçan olacak şekilde, gebelik süresi boyunca günde iki saat WiFi radyasyon maruziyetine uğrayan deney grubu ve WiFi maruziyete uğramaksızın aynı koşullarda tutulan kontrol grubu olmak üzere iki gruba ayrılmıştır. Doğumdan sonra (postnatal) dönemin 17. gününde sıçan yavrularının fiziksel ve nörogelişimsel durumları, 28. gününde anksiyeteleri, 40-43. günlerinde motor (motricity) durumları ve 28-43. günlerinde ise beyin doku ve serumlarındaki serebral oksidatif stres yanıtları ve kolinesteraz aktiviteleri değerlendirilmiştir. Çalışma bulguları, rahim içi (in utero) WiFi maruziyetinin, yetişkin dönemde duygusal (emosyonel) ve motor davranışlarını değiştirmeksizin, postnatal dönemin ilk 17 günü boyunca sıçan yavrularının nörogelişimlerini bozduğunu göstermiştir. Fakat maternal WiFi radyasyon maruziyeti, sıçan yavrularının duygusal (emosyonel) davranışını etkilememiştir. Çünkü EPM testi sonuçlarına göre, sıçan yavrularının labirentin açık kollarına giriş sayısı ve bu kollarda kalma zamanı açısından deney grubu ile kontrol grubu arasında anlamlı bir fark saptanmamıştır $(p>0,05)$. Ayrıca doğum öncesi (prenatal) WiFi maruziyeti, 28. günde serebral oksidatif stres parametrelerinde dengesizliğe (MDA ve hidrojen peroksit $\left(\mathrm{H}_{2} \mathrm{O}_{2}\right)$ düzeylerinde artış ile CAT ve SOD 
aktivitelerinde azalma) neden olmuştur. WiFi maruziyetine uğramış yavruların, postnatal dönemin 28 . ve 43. günlerinde serebral AChE aktivitesi anlamlı bir şekilde artar iken, 43. gününde serik bütirilkolinesteraz aktivitesi azalmıştır. Sonuç olarak çalışmada, maternal WiFi RF maruziyetin, sıçan yavrularının nörogelişim, serebral stres dengesi ve kolinesteraz aktivitelerini etkileyerek sıçanlarda olumsuz nörolojik etkilere yol açtığı ortaya konulmuştur (Tablo 4).

Othman ve arkadaşlarının (36) diğer bir çalışmalarında ise, tekrarlayıcı stres kısıtlaması ve/veya $2450 \mathrm{MHz} \mathrm{WiFi}$ maruziyetin, erkek Wistar Albino sıçanlarda ( $\mathrm{n}=24,230$ 250 gr) MSS'de antioksidan savunma (oksidatif stres), bilişsel (kognitif) fonksiyonlar ve davranış (anksiyete ve hafıza) üzerindeki etkileri araştırılmıştır. Çalışmadaki sıçanlar, önceki çalışmalarındaki (34) deney protokolüne benzer şekilde, rastgele olarak her bir grupta altı sıçan olacak şekilde kontrol, WiFi maruziyet, kısıtlanmış grup ve hem kısıtlanmış hem de WiFi maruziyete uğramış kombine grup olmak üzere toplam dört deney grubuna ayrılmıştır. Kısıtlayıcı stres ve/veya $\mathrm{WiFi}$ maruziyet gruplarının her birine, 20 gün boyunca günde iki saat stres ve/veya WiFi maruziyeti uygulanmıştır. Daha sonra her bir deney grubu için anksiyete davranışları EPM ve uzaysal öğrenme, hafiza becerileri ise MWM davranış testleri ile değerlendirilmiş, biyokimyasal analizler ile sıçan beyin dokuları ve serumlarından oksidatif stres parametreleri (MDA, SOD, CAT aktiviteleri, thiol (-SH) seviyesi) ve kolinesteraz aktiviteleri ölçülmüştür. Çalışma bulguları, WiFi maruziyeti veya stres kısıtlamasının, ayrı ayrı olarak ve özellikle kombine uygulamasının, siçanlarda uzaysal öğrenme ve hafiza becerilerini bozmaksızın, anksiyete benzeri davranışa neden olduğunu ortaya koymuştur. Ayrıca, WiFi maruziyeti veya stres kısıtlamasının, özelliklede her iki maruziyetin kombine uygulanmasının sıçan beyninde oksidatif stres yanıtını indüklediği (MDA aktivitesi ve thiol (-SH) seviyesinde artma ile CAT aktivitesinde artma/azalma) ve ayrıca kontrol grubuna göre tek başına WiFi maruziyeti uygulamasının AChE aktivitesinde anlamlı artışa neden olduğu da belirlenmiştir. Ek olarak çalışmada, sıçan beyinleri üzerinde WiFi sinyal ve stres kısıtlamasının birleşik (sinerjik) bir etkisinin olmadığı da gösterilmiştir (Tablo 4).

Kumar ve arkadaşları (37) çalışmalarında, yetişkin erkek Swiss fareler ( $\mathrm{n=21}$ ) üzerinde, "genlik modülasyonlu', ve “'modülasyonlu olmayan”, MWR'nun anksiyete ve depresyon benzeri davranış olmak üzere davranışsal etkileri ile beyin dokusunda kalsiyum ve nitrik oksit (NO) ilişkili biyokimyasal etkilerini araştırmışlardır. Çalışmadaki fareler, her bir grupta yedi fare olacak şekilde sürekli sinüzoidal modülasyonlu (SAR: 0,019 $\mathrm{W} / \mathrm{Kg}$, güç yoğunluğu: $0,029 \mathrm{~mW} / \mathrm{cm}^{2}, 400 \mathrm{~Hz}$ modülasyon sinyali, \% 0,1 modülasyon indeksi) ve modüle olmamış (SAR: 0,023 W/Kg, güç yoğunluğu: 0,033 $\mathrm{mW} / \mathrm{cm}^{2}$ ) kronik $2450 \mathrm{MHz}$ MWR'a bir ay boyunca günde iki saat olacak şekilde maruz bırakılmışlardır. Kontrol grubu olarak sham maruziyet grubu fareler $(n=7)$, herhangi bir MWR uğramaksızın sessiz bir odaya yerleştirilmiştir. Deneyde MWR maruziyeti, sinyal jeneratörü veya mikrodalga kaynağ (frekans aralığı: $250 \mathrm{KHz}-20 \mathrm{GHz}$ ) ile uygulanmıştır. Kontrol ve MWR maruziyet grubundaki sıçanların motor koordinasyon davranışları, rotarod testi, anksiyete ve anksiyete benzeri davranışları EPM ve OF testleri, depresyon benzeri davranışları FST ile değerlendirilmiştir. Ayrıca çalışmada beyin doku homejenatlarından AChE aktivitesi, nitrat-nitrit ve intrasellüler kalsiyum seviyeleri ile plazma kortikosteron ve kan glukoz düzeyleri de belirlenmiştir. Rotarod testinde, kontrol grubu ile karşılaştırıldığında, modüle ve modüle olmayan MWR maruziyetine uğrayan farelerde, motor aktivite açısından anlamlı bir fark bulunmamıştır. EPM testinde, kontrol grubu farelere göre kronik modüle olmamış MWR'a maruz kalan farelerde, açık kollara girişlerde anlamlı azalmalar $(\mathrm{p}<0,05)$ ve açık kolda harcanan zamanlarda da anlamlı olamayan derecede azalmalar görülmüştür. Fakat kontrol grubu farelere kıyasla kronik modüle olan MWR' a maruz kalan farelerde açık kollara giriş ve bu kollarda harcanan zaman açısından bu tür azalmalar gözlenmemiştir. OF testinde, kontrol grubu farelere göre kronik modüle olmamış MWR' a maruz kalan farelerde, açık alana girişler ve açık alanın merkez bölgesinde harcanan zamanda anlamlı azalmalar saptanmıştır $(\mathrm{p}<0,05)$. Farelerdeki süslenme (grooming) davranışı kontrol grubuna göre modüle olmamış MWR'a maruz kalan farelerde anlamlı derecede baskılanmıştır $(p<0,05)$. FST sonuçlarında, kontrol grubuna göre kronik modüle olmamış MWR'a maruz kalan farelerde anlamlı derecede FST'de artan hareketsizlik belirlenir iken $(p<0,05)$, modüle olan MWR'a maruz kalan farelerde, depresyon benzeri davranış üzerinde herhangi bir anlamlı etki gözlenmemiştir. Özetle davranış testi sonuçları, kronik modüle olmamış MWR maruziyetin, anksiyete ve depresyon benzeri davranışları ortaya çıkardığını göstermiştir. Hipokampüsteki AChE aktivitesi ve intrasellüler kalsiyum seviyeleri, kontrol grubuna göre kronik modüle olmamış MWR'a maruz kalan farelerde anlamlı derecede artmış (her biri için $\mathrm{p}<0,05$ ) olmasına rağmen, modüle olmuş MWR maruziyetinin serebral korteksteki AChE aktivitesi ve kalsiyum seviyeleri üzerinde anlamlı etkileri bulunmamıştır. Ayrıca kontrol grubuna göre kronik modüle olan MWR'a maruz kalan farelerde, korteks ve hipokampüsteki kalsiyum seviyelerinde anlamlı olmayan bir değişim gözlenmiştir. Ek olarak, kontrol grubuna göre kronik modüle olmamış MWR'a maruz kalan farelerde, hipokampüsteki nitratnitrit ve kandaki kortikosteron seviyelerinde anlamlı bir artış (her biri için $\mathrm{p}<0,05$ ) belirlenmesine karşın, kronik modüle olan MWR'a maruz kalan farelerde bu parametreler açısından anlamlı herhangi bir etki gözlenmemiştir. Dolayısıyla biyokimyasal sonuçlar, kronik modüle olmayan MWR maruziyetinin, beyinde AChE aktivitesi, NO ve intrasellüler kalsiyum seviyeleri ile kandaki glukoz ve kortikosteron düzeylerinde anlamlı artışa neden olduğunu ortaya koymuştur (Tablo 4).

Cosquer ve arkadaşlarının (38) gerçekleştirdiği üç deneysel kısımdan oluşan çalışmanın, ilk iki deneysel kısımlarında (Deney 1, 2), EPM testi ile farklı 1 şık şiddetine sahip ortamlardaki (200, 30, 10 ve 2,5 lux) erkek Sprague-Dawley siçanlarda ( $\mathrm{n}=20,270-320$ gr), anksiyete yanıtlarının yanı sira, diazepem (DZP) (30 lux'de ip 0,5 ve $10 \mathrm{mg} / \mathrm{kg}$ ) uygulamasının etkileri araştırılmıştır. Çalışmanın ilk iki kısmından elde edilen 
Tablo 4. $2100 \mathrm{MHz}, 2450 \mathrm{MHz}, 2500 \mathrm{MHz}$ veya $9417 \mathrm{MHz}$ RF/MW-EMR maruziyetlerine ait literatür çalışmaları ve sonuçları

\begin{tabular}{|c|c|c|c|c|c|c|c|c|c|}
\hline $\begin{array}{l}\text { Yazar ve Yayın } \\
\text { Yılı } \\
\text { (Kaynak no) }\end{array}$ & $\begin{array}{l}\text { Çalışılan } \\
\text { Frekans } \\
\text { (MHz) }\end{array}$ & $\begin{array}{l}\text { Spesifik } \\
\text { absorbsiyon } \\
\text { oranı } \\
\text { (SAR, W/kg) }\end{array}$ & $\begin{array}{lr}\text { Güç } & \text { yoğunluğu } \\
\text { veya } & \text { elektrik } \\
\text { alan } & \end{array}$ & $\begin{array}{l}\begin{array}{l}\text { Maruziyet } \\
\text { sistemi } \\
\text { kurulumu }\end{array} \\
\text { veya }\end{array}$ & $\begin{array}{l}\text { Maruziyet } \\
\text { süresi }\end{array}$ & $\begin{array}{l}\text { Maruziyet } \\
\text { bölgesi (tüm } \\
\text { vücut/baş/karı } \\
\text { n (abdomen)) }\end{array}$ & $\begin{array}{l}\text { Hayvan } \\
\text { modeli } \\
\text { (yaş) }\end{array}$ & Çalışılan parametreler & Çalışmanın sonuçları \\
\hline $\begin{array}{l}\text { Sharma ve ark. } \\
2019 \text { (33) }\end{array}$ & $2100 \mathrm{MHz}$ & $0,453 \mathrm{~W} / \mathrm{kg}$ & Bildirilmemiştir. & $\begin{array}{l}2100 \mathrm{MHz} \text { frekans } \\
\text { sinyalleri üreten } \\
\text { EMA jenaratör }\end{array}$ & $\begin{array}{lr}90 \text { gün (3 } & \text { ay) } \\
\text { boyunca } & 5 \\
\text { gün/hafta } & \text { ve } \\
4 \text { saat/gün } & \end{array}$ & Baş bölgesi & $\begin{array}{l}\text { Erkek } \\
\text { Wistar } \\
\text { Albino } \\
\text { siçan }\end{array}$ & $\begin{array}{l}\text { Anksiyete, } \begin{array}{r}\text { uzaysal } \\
\text { nöromuskular }\end{array} \text { fonksiyon, } \\
\text { oksidatif savunma sistemi } \\
\text { (LPO, GSH, SOD, CAT) } \\
\begin{array}{l}\text { parametereleri, } \\
\text { hipokampüs dokusu }\end{array}\end{array}$ & $\begin{array}{l}\text { MWR maruziyeti; anksiyetede artma ile birlikte, hafiza, } \\
\text { öğrenme yeteneği, kas kuvveti, oksidatif savunma sistemi ve } \\
\text { AChE parametreleri ile hipokampüs dejenereasyonunda } \\
\text { anlamlı değişiklere neden olmuştur ( } \leq 0,001) \text {. }\end{array}$ \\
\hline $\begin{array}{l}\text { Varghese ve } \\
\text { ark. } 2018 \text { (6) }\end{array}$ & $2450 \mathrm{MHz}$ & Bildirilmemiştir. & $7,88 \mathrm{~W} / \mathrm{m}^{2}$ & $\begin{array}{l}2450 \quad \mathrm{MHz} \\
\text { radyasyon } \\
\text { maruziyet sistemi }\end{array}$ & $\begin{array}{l}45 \text { gün boyunca } \\
\text { günde } \\
\text { saat/gün }\end{array}$ & Tüm vücut & $\begin{array}{l}\text { Dişi } \\
\text { Sprague- } \\
\text { Dawley } \\
\text { siçan } \\
\end{array}$ & $\begin{array}{l}\text { Anksiyete, öğrenme ve hafiza } \\
\text { performansları, oksidatif stres } \\
\text { parametreleri, kaspaz } 3 \text { gen } \\
\text { ekspresyon seviyeleri }\end{array}$ & $\begin{array}{l}\text { MWR maruziyetinin, beyin antioksidan enzim sistemlerinde } \\
\text { çöküş ile birlikte, öğrenme ve hafizanın azalması ve } \\
\text { anksiyete davranışlarının oluşumuna neden olduğ } \\
\text { belirlenmiştir. }\end{array}$ \\
\hline $\begin{array}{l}\text { Othman ve ark. } \\
\text { 2017a (34) }\end{array}$ & $2450 \mathrm{MHz}$ & Bildirilmemiştir. & Bildirilmemiştir. & $\begin{array}{lr}2450 & \mathrm{MHz} \\
\text { sinyalleri üreten } \\
\text { WiFi maruziyet }\end{array}$ & $\begin{array}{l}\text { Gebelik süresi } \\
\text { boyunca } \\
\text { doğuma kadar } 2\end{array}$ & Tüm vücut & $\begin{array}{l}\text { Dişi } \\
\text { Wistar } \\
\text { Albino }\end{array}$ & 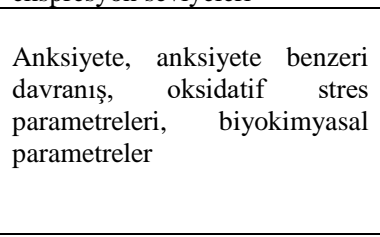 & $\begin{array}{l}\text { Maternal WiFi maruziyeti ve/veya stres kisıtlama } \\
\text { uygulamasının, yetişkin siçanlarda anksiyete benzeri } \\
\text { davranış, motor eksikliği, keşif davranışlarını olumsuz } \\
\text { yönde etkiler iken, her iki cinsiyetteki yavruların beyin } \\
\text { oksidatif stres parametrelerinde dengesizlik oluşumu ile } \\
\text { birlikte cinsiyete bağımlı olarak serum biyokimyasal } \\
\text { parametrelerinde bozulmalara neden olmuştur. }\end{array}$ \\
\hline $\begin{array}{l}\text { Othman ve ark. } \\
\text { 2017b (35) }\end{array}$ & & & & sistemi & saat/gün & & $\begin{array}{l}\text { gebe } \\
\text { siçan }\end{array}$ & 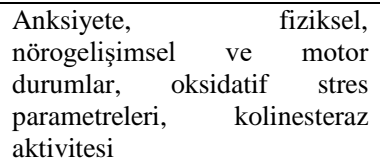 & $\begin{array}{l}\text { Maternal WiFi maruziyeti, sıçan yavrularının duygusal } \\
\text { (emosyonel) davranı̧ında herhangi bir değişikliğe neden } \\
\text { olmazken iken, nörogelişim, serebral stres dengesi ve } \\
\text { kolinesteraz aktivitelerini etkilemiştir. }\end{array}$ \\
\hline $\begin{array}{l}\text { Othman ve ark. } \\
\text { 2017c (36) }\end{array}$ & & & & & $\begin{array}{l}20 \text { gün boyunca } \\
2 \text { saat/gün }\end{array}$ & & $\begin{array}{l}\text { Erkek } \\
\text { Wistar } \\
\text { Albino } \\
\text { sıçan }\end{array}$ & $\begin{array}{l}\text { Anksiyete, uzaysal öğrenme ve } \\
\text { hafiza, oksidatif stres } \\
\text { parametreleri, kolinesteraz } \\
\text { aktivitesi }\end{array}$ & $\begin{array}{l}\text { WiFi maruziyeti ve/veya stres kısıtlama uygulamasının, } \\
\text { siçanlarda uzaysal öğrenme ve hafiza becerilerini bozmaksızın, } \\
\text { anksiyete benzeri davranışa neden olur iken, oksidatif stres } \\
\text { yanıtını indüklemiş ve tek başına WiFi maruziyeti kontrol } \\
\text { grubuna göre AChE aktivitesini arttırmıştır. }\end{array}$ \\
\hline
\end{tabular}

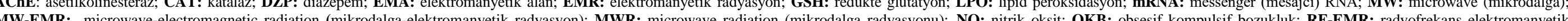
radyasyon; SAR: specific absorbation rate (spesifik absorbiyon oranı); SOD: süperoksit dismutaz; WiFi: wireless-fidelity (kablosuz bağlantı alanı); WM: working memory (çalışma belleği) 
Tablo 4. $2100 \mathrm{MHz}, 2450 \mathrm{MHz}, 2500 \mathrm{MHz}$ veya $9417 \mathrm{MHz}$ RF/MW-EMR maruziyetlerine ait literatür çalışmaları ve sonuçları (devamı)

\begin{tabular}{|c|c|c|c|c|c|c|c|c|c|}
\hline $\begin{array}{l}\text { Yazar ve Yayın } \\
\text { Yılı } \\
\text { (Kaynak no) }\end{array}$ & $\begin{array}{l}\text { Çalşsılan } \\
\text { Frekans } \\
\text { (MHz) }\end{array}$ & $\begin{array}{l}\text { Spesifik } \\
\text { absorbsiyon } \\
\text { oranı } \\
\text { (SAR, W/kg) }\end{array}$ & $\begin{array}{l}\text { Güç } \\
\text { veya } \\
\text { alan }\end{array}$ & $\begin{array}{l}\text { Maruziyet } \\
\text { sistemi } \\
\text { kurulumu }\end{array}$ veya & $\begin{array}{l}\text { Maruziyet } \\
\text { süresi }\end{array}$ & $\begin{array}{l}\text { Maruziyet } \\
\text { bölgesi (tüm } \\
\text { vücut/baş/karın } \\
\text { (abdomen)) }\end{array}$ & $\begin{array}{l}\text { Hayvan } \\
\text { modeli } \\
\text { (yaş) }\end{array}$ & Çalışılan parametreler & Çalışmanın sonuçları \\
\hline $\begin{array}{l}\text { Kumar ve ark. } \\
2016 \text { (37) }\end{array}$ & $2450 \mathrm{MHz}$ & $\begin{array}{l}0,019 \mathrm{~W} / \mathrm{kg} \\
0,023 \mathrm{~W} / \mathrm{kg}\end{array}$ & $\begin{array}{l}0,029 \mathrm{~mW} / \mathrm{cm}^{2} \\
0,033 \mathrm{~mW} / \mathrm{cm}^{2}\end{array}$ & $\begin{array}{l}250 \mathrm{KHz}-20 \mathrm{GHz} \\
\text { frekans aralığında } \\
\text { MW kaynağı veya } \\
\text { sinyal jeneratörü }\end{array}$ & $\begin{array}{l}1 \text { ay boyunca } \\
2 \text { saat/gün }\end{array}$ & Tüm vücut & $\begin{array}{l}\text { Yetişkin } \\
\text { erkek Swiss } \\
\text { Albino fare }\end{array}$ & $\begin{array}{lr}\text { Anksiyete, } & \text { anksiyete ve } \\
\text { depresyon } & \text { benzeri davranıs, } \\
\text { motor } & \text { koordinasyon } \\
\text { davranışı, } & \text { kalsiyum ve NO } \\
\text { ilişkili } & \text { biyokimyasal } \\
\text { parametreler } & \\
\end{array}$ & $\begin{array}{l}\text { Kronik modüle olmamış MWR maruziyeti, farelerde } \\
\text { anksiyete ve depresyon benzeri davranışlara neden } \\
\text { olmuştur. Kontrol grubuna göre modüle olmamış MWR'a } \\
\text { maruz kalan farelerde, hipokampüsteki AChE aktivitesi, } \\
\text { intrasellüler kalsiyum ve NO seviyeleri ile kandaki glukoz } \\
\text { ve kortikosteron düzeyleri anlamlı derecede artmıştır. }\end{array}$ \\
\hline $\begin{array}{l}\text { Cosquer ve ark. } \\
2005 \text { (38) }\end{array}$ & $2450 \mathrm{MHz}$ & $\begin{array}{l}0,6 \mathrm{~W} / \mathrm{kg} \pm 2 \mathrm{~dB} \\
\text { (tüm vücut) } \\
0,9 \mathrm{~W} / \mathrm{kg} \pm 3 \mathrm{~dB} \\
\text { (baş) }\end{array}$ & Bildirilmemiştir. & $\begin{array}{lr}2450 & \mathrm{MHz} \\
\text { sinyalleri üreten } \\
\text { EMR maruziyet } \\
\text { sistemi }\end{array}$ & 45 dakika/gün & $\begin{array}{l}\text { Tüm vücut, } \\
\text { baş bölgesi }\end{array}$ & $\begin{array}{l}\text { Sprague- } \\
\text { Dawley } \\
\text { sıçan }\end{array}$ & $\begin{array}{l}\text { Anksiyete yanıtları, ortam } \\
\text { ş̧ık şiddeti yanıtları }\end{array}$ & $\begin{array}{l}\text { Anksiyete yanıtlarının azalan 1şı şiddeti ile azalır iken, } \\
\text { DZP uygulaması ile hafifflediği belirlenmiş̧tir. Ayrıca } \\
2450 \mathrm{MHz} \text { EMR maruziyeti } 1 \text { şı şiddetine bağlı } \\
\text { olmaksızın anksiyete yanıtlar /anksiyete benzeri } \\
\text { davranışlar üzerine anlamlı bir etki oluşturmamıştır. }\end{array}$ \\
\hline $\begin{array}{l}\text { Salunke ve ark. } \\
2015 \text { (7) }\end{array}$ & $2450 \mathrm{MHz}$ & Bildirilmemiştir. & $\begin{array}{l}10 \mathrm{~mW}-100 \mathrm{~mW} \\
\text { arasinda }\end{array}$ & $\begin{array}{l}2450 \text { MHz ile } \\
\text { çalşsan bluetooth } \\
\text { donanımını } \\
\text { kullanan iki çift } \\
\text { cep telefonu }\end{array}$ & $\begin{array}{l}7,30,60,90 \\
\text { veya } 120 \text { gün } \\
\text { boyunca } 60 \\
\text { dakika/gün }\end{array}$ & Tüm vücut & $\begin{array}{l}\text { Erkek } \\
\text { Swiss } \\
\text { Albino fare }\end{array}$ & $\begin{array}{l}\text { Anksiyete, OKB, depresyon } \\
\text { benzeri davranış, lokomotor } \\
\text { aktivite }\end{array}$ & $\begin{array}{l}\text { Yüksek frekanslı EMA'a 120 gün boyunca maruz } \\
\text { kalmanın, farelerin anksiyete, OKB, depresyon- benzeri } \\
\text { davranış, lokomotor aktivite üzerine anlamlı bir etkisi } \\
\text { gözlenmemiştir. }\end{array}$ \\
\hline $\begin{array}{l}\text { Obajuluwa ve } \\
\text { ark. } 2017 \text { (39) }\end{array}$ & $2500 \mathrm{MHz}$ & Bildirilmemiştir. & $\begin{array}{l}\text { Elektrik } \\
\text { yoğunluğu, } \\
11 \mathrm{~V} / \mathrm{m}\end{array}$ & $\begin{array}{l}2500 \mathrm{MHz} \text { WiFi } \\
\text { sinyalleri üreten } \\
\text { sinyal cihazı }\end{array}$ & $\begin{array}{l}\begin{array}{l}4,6 \text { ve } 8 \text { hafta } \\
\text { boyunca } \\
\text { saat/gün }\end{array} \\
\end{array}$ & Tüm vücut & $\begin{array}{l}\text { Erkek } \\
\text { Albino } \\
\text { Sıçan } \\
\text { (4 haftalık) }\end{array}$ & $\begin{array}{l}\text { Anksiyete ilişkili davranış, } \\
\text { lokomotor aktivite, korteks } \\
\text { AChE aktivitesi, mRNA } \\
\text { ekspresyon seviyeleri }\end{array}$ & $\begin{array}{l}\text { RF-EMR maruziyeti sonucu, anksiyete ve AChE mRNA } \\
\text { ekspresyon seviyelerinde artma, lokomotor ve AChE } \\
\text { aktivitetelerinde azalma saptanmıştır. }\end{array}$ \\
\hline $\begin{array}{l}\text { Zhang ve ark. } \\
2015 \text { (40) }\end{array}$ & $9417 \mathrm{MHz}$ & $2,0 \mathrm{~W} / \mathrm{Kg}$ & $\begin{array}{l}\text { Radyasyon gücü, } \\
1,93 \mathrm{~W}, \\
\text { şiddeti } 200 \mathrm{~V} / \mathrm{m}\end{array}$ & $\begin{array}{lr}9417 \quad \mathrm{MHz} \\
\text { sinyalleri üreten } \\
\text { EMR maruziyet } \\
\text { sistemi }\end{array}$ & $\begin{array}{l}14 \text { gün boyunca } \\
2 \text { saat/gün }\end{array}$ & Tüm vücut & $\begin{array}{ll}\text { Dişi } & \text { CD1 } \\
\text { fare }\end{array}$ & $\begin{array}{l}\text { Anksiyete ilişkili davranış, } \\
\text { depresyon ilişkili davranış, } \\
\text { öğrenme-hafıza davranışları }\end{array}$ & $\begin{array}{l}\text { Rahim içi (in utero) MW-EMR maruziyeti erkek ve dişi } \\
\text { fare yavrularında anksiyete ilişkili davranışta artma, } \\
\text { depresyon ilişkili davranışta azalmaya neden olmuştur. } \\
\text { Ayrıca MW-EMR maruziyeti, erkek farelerde öğrenme ve } \\
\text { hafizayı azaltırken, dişi yavrularda öğrenme-hafıza } \\
\text { üzerinde herhangi bir etki oluşturmamış̧ır. }\end{array}$ \\
\hline
\end{tabular}

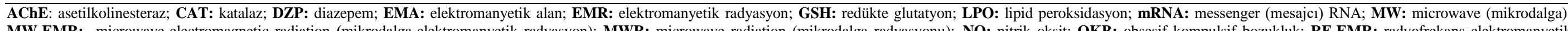

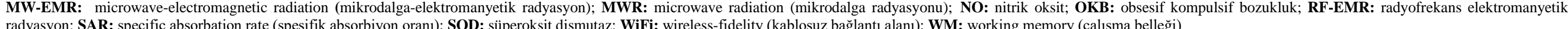


bulgulardan, anksiyete yanıtlarının azalan 1 şı şiddeti ile azalır iken, DPZ uygulaması ile hafiflediği belirlenmiştir. Çalışmanın diğer deneysel kısmında (Deney 3), aynı cins fakat ayrı bir Sprague-Dawley sıçan ( $n=72,270-320$ gr) grubu, 45 dakika süreyle $2450 \mathrm{MHz}$ EMR'lara ( $2 \mu \mathrm{sn}$ puls genişliği, 500 pps (pulses per second; saniyedeki puls say1s1), tüm vücut ortalama SAR: $0,6 \mathrm{~W} / \mathrm{kg} \pm 2 \mathrm{~dB}$, beyin ortalama SAR: 0,9 W/kg $\pm 3 \mathrm{~dB}$ ) maruziyetlerin sıçanların anksiyete yanıtlarını değiştirip değiştirmediği EPM testi ile değerlendirilmiştir. EPM testi öncesi, deney 3 kısmındaki sıçanların bir çifti 45 dakika eş zamanlı olarak $2450 \mathrm{MHz}$ EMR'a maruz birakılan 'EMR grubu”, (30 lux koşulunda $n=12$ ve 2,5 lux koşulunda $n=12$ ), diğer sıçan çifti 45 dakika aynı dalga kılavuzunda fakat 1şınlanmamış "sham grubu" (30 lux koşulunda $n=12$ ve 2,5 lux koşulunda $n=12$ ) ve geri kalan diğer sıçan çifti ise test odasina getirilen fakat teste başlamadan önce maruziyet sistemi ile bağlantısı olmayan "saf (naive) grubu', (30 lux koşulunda $n=12$ ve 2,5 lux koşulunda $\mathrm{n}=12$ ) olarak toplam üç grupta incelenmiştir. Bu deneyde, 1 şık şiddetine bağlı etkilerin anksiyojenik veya anksiyolitik olup olmadığına dair önceden bir hipotez olmadığı için, sıçan çiftleri iki farklı 1şık şiddetlerindeki (30 lux ve 2,5 lux) ortamlarda değerlendirilmiştir. Düşük 1 şık şiddet seviyesindeki grup, anksiyojenik etkileri belirlemek için davranışsal başlangıç (baseline) kabul edilmiş, yüksek 1 şı şiddet seviyesindeki grup anksiyolitik etkilerin belirlenmesine karşılık incelenmiştir. Deneyde sham-maruziyet ve saf (naive) sıçanlar kontrol olarak kullanılmıştır. EMR maruziyet sonrası uygulanan EPM testi sonuçlarına göre, hangi 1 şı şiddeti kullanılırsa kullanılsın, $2450 \mathrm{MHz}$ EMR maruziyetinin (bir günde 45 dakika) sıçanların anksiyete yanıtları/anksiyete benzeri davranışları üzerine anlamlı bir etki oluşturmadığı ortaya konulmuştur (Tablo 4).

Salunke ve arkadaşları (7) çalışmalarında, erkek Swiss Albino farelerde (22-26 gr), uzun süreli yüksek frekanslı EMA maruziyetinin, anksiyete, obsesif kompulsif bozukluk (OKB), depresyon benzeri davranış ve lokomotor aktivite üzerindeki etkilerini araştırmay1 amaçlamışlardır. Çalışmadaki fareler, kontrol ve yüksek frekanslı EMA maruziyet deney grupları olarak toplam iki gruba ayrılmış olup, deney grubundaki fareler, yedi, 30, 60, 90 veya 120 gün boyunca günde 60 dakika 2450 $\mathrm{MHz}$ EMA'a maruz bırakılmışlardır. Her bir grup rastgele olacak seçilmiş olan altı veya sekiz fare içermektedir. Yüksek frekanslı EMA maruziyet sistemi, içinde sınıf-I bluetooth donanınımı gömülü olan piyasada mevcut olan iki cep telefonu (Nokia 2700) ile oluşturulmuştur. Deney grubundaki farelere yüksek frekanslı EMA maruziyeti, aynı kafeste yer alan cep telefonlarının iki aktive bluetooth donanımları arasında veri dosyalarının transferi (pik (tepe) yoğunluğu 100 mW'daki dosya transfer modunda $2450 \mathrm{MHz}$ frekansı kullanan gömülü sınıf-I bluetooth donanınımının açılmasıyla) ile gerçeklemiştir. Kontrol grubundaki fareler ise aynı koşullarda tutulmuş, fakat yüksek frekanslı EMA'a maruz bırakılmamışlardır. Daha sonra, deney ve kontrol grubundaki farelerin, yedi, 30, 60, 90 veya 120 günlük maruziyetler için anksiyete, OKB, depresyon benzeri davranış ve lokomotor aktiviteleri belirlenmiştir. Anksiyete benzeri davranış; EPM, OF ve sosyal etkileşim (SI: social interaction) testleri, OKB benzeri davranış; bilye gömme davranışı (marble-burying behavior) ve depresyon benzeri davranış; FST, TST ile değerlendirilmiştir. Ayrıca lokomotor aktivite ise, anksiyete ve OKB benzeri davranış için gerçekleştirilen ilgili testler sırasında, eş zamanlı olarak hayvanların hareketlerinin gözlenmesi ile ölçülmüştür. Çalışma bulgularında, yüksek frekanslı (2450 MHz) EMA'a 120 gün kadar uzun süreli maruziyetin anksiyete, OKB, depresyon benzeri davranışlar ve lokomotor aktivitede üzerine anlamlı bir etkisi saptanmamıştır (Tablo 4).

Obajuluwa ve arkadaşları (39) çalışmalarında, erkek Albino sıçanlarda ( $n=24$, dört haftalık), $2500 \mathrm{MHz}$ RFEMR maruziyetin, anksiyete ilişkili davranışlar, lokomotor fonksiyon, serebral korteks AChE aktivitesi ve mRNA ekspresyon düzeyleri üzerindeki etkilerini araştırmışlardır. Çalışmadaki sıçanlar, maruziyete uğramayan grup 1, ve sirasıyla dört, altı ve sekiz hafta süreyle $2500 \mathrm{MHz}$ RF-EMR maruziyetine uğrayan gruplar 2-4 olarak isimlendirilerek, toplam dört grupta incelenmiştir. Çalışmada, RF-EMR maruziyet sistemi olarak, yaklaşık $2500 \mathrm{MHz}$ frekans bandında Wi-Fi sinyalleri yayan sinyal cihazı kullanılmıştır. Maruziyetin son gününde, OF ve rotarod performs testleri gibi nörodavranışsal analizler ile deney gruplarındaki sıçanların lokomotor aktivite, anksiyete ve motor koordinasyon düzeyleri değerlendirilmiştir. Çalışma bulgularında Wi-Fi maruziyetinin, anksiyete düzeylerinde anlamlı artışlara, lokomotor aktivitelerinde ise anlamlı azalmalara neden olduğu saptanmıştır. Ayrıca kontrol grubu ile karşılaştırıldığında, Wi-Fi maruziyetine uğrayan sıçanların AChE mRNA düzeylerindeki artış ile eş zamanlı olarak AChE aktivitelerinde anlamlı azalmalar belirlenmiştir $(p<0,05)$. Sonuç olarak çalışmada, uzun süreli Wi-Fi maruziyetinin, AChE gen ekspresyonu ve beyin hasarı ile ilişkili bazı nörodavranışsal parametreler üzerinde anlamlı değişiklik nedeniyle nörodejeneratif hastalıklar gibi olumsuz etkilere yol açabileceği gösterilmiştir (Tablo 4).

Zhang ve arkadaşları (40) çalışmalarında, gebelik dönemi boyunca (3., 5-18 günlerde) rahim içi (in utero) $9417 \mathrm{MHz}$ MW-EMR maruziyetinin cinsiyete bağlı olarak davranış üzerindeki etkilerini araştırmışlardır. Çalışmada kullanılan CD1 cinsi gebe fareler ( $\mathrm{n}=12), 14$ gün boyunca günde iki saat MW-EMR maruziyetine uğrayan "radyasyon grubu", EMR maruziyetine uğrayanlar ile aynı koşullarda tutulan fakat radyasyon kaynağının kapalı olduğu durumdaki "sham-kontrol grubu” ve radyasyon kaynağından dışarıda korumalı odada bulunan “kontrol grubu”' olarak toplam üç deney grubunda incelenmiştir. Doğumdan beş hafta sonra, sıçan yavrularının anksiyete ilişkili davranışları EPM ve OF testleri, depresyon ilişkili davranışları TST ve FST, öğrenme-hafıza davranışları MWM testi ile değerlendirilmiştir. Çalışmada rahim içi (in utero) MWEMR maruziyeti sonrası farelerin, deney alanının merkezinde (OF testinde) ve açık kolunda (EPM testinde) daha az hareket ettikleri gözlendiğinden, MW-EMR maruziyetinin farelerde anksiyete ilişkili davranışı arttırdığı saptanmıştır. Fakat rahim içi (in utero) MWEMR maruziyetinden sonra, TST ve FST'deki immobilitenin (hareketsizliğin) azaldığı gözlendiğinden, farelerde radyasyon maruziyetinin depresyon ilişkili davranışı azalttığı belirlenmiştir. Ayrıca MWM testi 
bulgularından, MW-EMR maruziyetinin erkek yavrularda öğrenme ve hafizayı azaltırken, dişi yavrularda öğrenme ve hafiza üzerine herhangi bir etkisi gözlenmediğinden, öğrenme ve hafiza üzerine MW-EMR maruziyetinin cinsiyet bağımlı etkisi ortaya konulmuştur. Başka bir deyişle bu sonuç, rahim içi (in utero) MW-EMR'a erkek ve dişi duyarlılıklarının farklı olduğunu göstermiştir. Özet olarak çalışmada fetal 9417 MHz MW-EMR maruziyetinin, farelerde yetişkinliğe kadar devam eden cinsiyete bağlı nörodavranışsal değişikliklere yol açtığ gösterilmiştir (Tablo 4).

\section{SONUÇ VE ÖNERILER}

$\mathrm{Bu}$ derleme, çoğunlukla cep telefonu teknolojisi ile ilişkili olan RF/MW-EMR maruziyetinin, anksiyete ve/veya depresyon gibi stres ilişkili duygusal (emosyonel) davranışlar üzerine olası etkilerini değerlendirebilmek amacıyla gerçekleştirilmiştir. Derleme amacı yönünde, araştırmada fare veya sıçan gibi deney hayvanları üzerinde RF/MW-EMR maruziyet etkilerine bağlı olarak gelişebilecek anksiyete ve/veya depresyon düzeylerini laboratuvar testleri ile inceleyen 2005-2019 yılları arasında yayınlanmış, 27'si anksiyete ve 4'ü anksiyete ve depresyon ilişkili olmak üzere toplam 31 çalışmanın sonuçları irdelenmiştir. Değerlendirilen literatür çalışma verilerine göre RF/MW-EMR maruziyetinin etkileri incelendiğinde, EMR'nun 19 anksiyete çalışması $(6,12,13,17,18,20,22,24,25,27-$ 29, 32-34, 36, 37, 39, 40) ve bir depresyon (37) çalışmasında pozitif, beş anksiyete çalışması $(16,22,23$, 30, 32) ile bir depresyon çalışmasında negatif (40) etkileri saptanırken, dokuz anksiyete $(7,14,15,19,21,26,31$, $35,38)$ ve üç depresyon $(7,25,37)$ çalışmalarında ise anlamlı bir etkisi saptanmamıştır. Ayrıca derlemede değerlendirilen çalışmalardaki RF/MW-EMR maruziyetinin anksiyete ve/veya depresyon üzerine etkilerine dayalı çelişkili sonuçların, hayvan modellerinde kullanılan farklı anksiyete ve/veya depresyon benzeri davranış testleri ve ölçüm parametreleri $(13,16,17)$, deneysel hayvan modeli özellikleri (hayvan cinsi, cinsiyeti vb) (22, 34), hayvanın nörogelişimsel süreçleri (30), deneysel RF/MW-EMR maruziyet sistemi kurulum koşulları ile maruziyet parametreleri (frekans şiddeti, genlik modülasyonu, SAR değeri vb) ve/veya çevresel şartlara karşı gelişen adaptasyon süreçlerine bağlı olarak uygulanan deneysel protokollerden (23, 32, 37) kaynaklanabileceği ortaya konulmuştur. Ek olarak derlemede değerlendirilen çalışmaların bir kısmında ise, anksiyete ve/veya depresyon davranış testleri ve ölçüm parametrelerinin yanı sıra, bu davranış bozukluklarının nörogelişimsel/nörodavranışsal mekanizmalarını anlamaya yönelik, biyokimyasal, fizyolojik, histopatolojik ve moleküler parametreler de değerlendirilmiş olduğundan, bu araştırmalarda daha kapsamlı ve farklı sonuçlar elde edilmiştir. Sonuç olarak araştırmada değerlendirilen literatür verilerine göre, yaygın olarak maruz kaldığımız RF/MW-EMR'nun, günümüzde artan sıklıkta gözlenen anksiyete ve/veya depresyon benzeri davranışsal bozuklukların oluşumunu etkileyebilme potansiyelinin yüksek olduğu gözlenmiştir. Ayrıca derlemede yer alan literatür veri sayısının az olması, değerlendirilen çalışmaların deney gruplarında farklılıklar bulunması (sham/kontrol, maruziyet grupları vb) ve/veya bazı çalışmaların sham/kontrol grubu içermemesi, incelenen çalışmaların bazılarında EMR ölçüm parametrelerine ait verilerin (SAR, güç yoğunluğu veya elektrik alan vb) bildirilmemiş olması ve bu çalışmaların bir kısmında da farklı deneysel davranış testlerinin (OF, EPM, HBT, SI testleri, SPT, FST, TST ve L/D kutu deneyi vb) kullanılarak, deneysel testlerden elde edilen davranışsal ölçüm parametrelerinin subjektif yorumlanması gibi nedenlerden dolayı bu araştırmada, yanlılık riski yüksek ve hatalı/çelişkili sonuçlar verebileceği düşünülerek meta analiz değerlendirilememesi bu araştırmanın sınırlılı̆̆ını oluşturmaktadır. Ancak gelecek çalışmalarda, litearüre EMR'nun anksiyete ve/veya depresyon üzerindeki etkilerine dayalı yeni ve eksiksiz/kapsamlı kapsamlı araştırmaların eklenmesi ile elde edilecek daha fazla sayıdaki literatür verileri doğrultusunda gerçekleşitirilmesi önerilen meta analitik araştırmaların, RF/MW-EMR maruziyetinin anksiyete ve depresyon üzerine gerçek etki büyüklüklerinin, yansız, doğru, hassas ve güvenilir olarak belirlenebilmesini sağlayarak, bilimsel verilere önemli bir katk1 sağlayabileceği öngörülmektedir. Bununla birlikte derleme bulguları doğrultusunda, anksiyete ve/veya depresyonu içeren duygusal (emosyonel) davranış bozuklukları üzerine RF/MW-EMR'nun zararlı etkilerini açıklığa kavuşturmak amacıyla, literatürdeki mevcut veriler 1şığında, standardize EMR maruziyet koşulları, detaylı dozimetrik ölçüm parametreleri ve belirli davranış bozukluğu test protokollerinin saptanarak uygulanması hedefleri çerçevesinde, nöral ve moleküler mekanizmalara dayalı ileri çalışmalar gerçekleştirilmesinin, nörodavranışsal bozuklukların etiyolojisini anlamada önemli bir katk1 sağlayabileceği düşünülmektedir.

\section{KAYNAKLAR}

1. Akdag MZ, Dasdag S, Canturk F, Karabulut D, Caner $\mathrm{Y}$, Adalier $\mathrm{N}$. Does prolonged radiofrequency radiation emitted from WiFi devices induce DNA damage in various tissues of rats? J Chem Neuroanat. 2016; 75(Pt B): 116-22.

2. Hardell L. World Health Organization, radiofrequency radiation and health - a hard nut to crack (Review). Int J Oncol. 2017; 51(2): 405-13.

3. Narayanan SN, Jetti R, Kesari KK, Kumar RS, Nayak SB, Bhat PG. Radiofrequency electromagnetic radiation-induced behavioral changes and their possible basis. Environ Sci Pollut Res. 2019; 26(30): 693-710.

4. Verma S, Gupta A, Kumar B. Interaction of radiofrequency radiation with biological systems: a comprehensive update on recent challenges. Def Life Sci J. 2019; 4(2): 83-90.

5. Megha K, Deshmukh PS, Banerjee BD, Tripathi AK, Ahmed R, Abegaonkar MP. Low intensity microwave radiation induced oxidative stress, inflammatory response and DNA damage in rat brain. Neurotoxicology. 2015; 51: 158-65.

6. Varghese R, Majumdar A, Kumar G, Shukla A. Rats exposed to $2.45 \mathrm{GHz}$ of non-ionizing radiation exhibit behavioral changes with increased brain expression of apoptotic caspase 3. Pathophysiology. 2018; 25(1): 19-30. 
7. Salunke BP, Umathe SN, Chavan JG. Behavioral ineffectiveness of high frequency electromagnetic field in mice. Physiol Behav. 2015; 140: 32-7.

8. ICNIRP, Guidelines for limiting exposure to timevarying electric, magnetic, and electromagnetic fields (up to $300 \mathrm{GHz}$ ). Health Phys. 1998; 74(4): 494-522.

9. Panagioti M, Scott C, Blakemore A, Coventry PA. Overview of the prevalence, impact, and management of depression and anxiety in chronic obstructive pulmonary disease. Int J Chronic Obstr Pulm Dis. 2014; 9: 1289-306.

10. Campos AC, Fogaça MV, Aguiar DC, Guimaraes FS. Animal models of anxiety disorders and stres. Rev Bras Psiquiatr. 2013; 35(2): 101-11.

11. Koç A, Solak Gümüş ZI. Deney hayvanlarında anksiyete çalışmaları. Türk Bilimsel Derlemeler Dergisi. 2018; 11(2): 51-7.

12. Daniels WM, Pitout IL, Afullo TJ, Mabandla MV. The effect of electromagnetic radiation in the mobile phone range on the behaviour of the rat. Metab Brain Dis. 2009; 24(4): 629-41.

13. Petitdant N, Lecomte A, Robidel F, Gamez C, Blazy $\mathrm{K}$, Villégier AS. Alteration of adaptive behaviors of progeny after maternal mobile phone exposure. Environ Sci Pollut Res Int. 2018; 25(11): 10894-903.

14. Petitdant N, Lecomte A, Robidel F, Gamez C, Blazy $\mathrm{K}$, Villégier AS. Cerebral radiofrequency exposures during adolescence: impacton astrocytes and brain functions in healthy and pathologic rat models. Bioelectromagnetics. 2016; 37(5): 338-50.

15. Barthélémy A, Mouchard A, Bouji M, Blazy K, Puigsegur R, Villégier AS. Glial markers and emotional memory in rats following acute cerebral radiofrequency exposures. Environ Sci Pollut Res. 2016; 23(24): 25343-55.

16. Bouji M, Lecomte A, Gamez C, Blazy K, Villégier AS. Neurobiological effects of repeated radiofrequency exposures in male senescent rats. Biogerontology. 2016; 17(5-6): 841-57.

17. Saikhedkar N, Bhatnagar M, Jain A, Sukhwal P, Sharma C, Jaiswal N. Effects of mobile phone radiation (900 $\mathrm{MHz}$ radiofrequency) on structure and functions of rat brain. Neurol Res. 2014; 36(12) :1072-9.

18. Narayanan SN, Kumar RS, Paval J, Kedage V, Bhat MS, Nayak S, et al. Analysis of emotionality and locomotion in radio-frequency electromagnetic radiation exposed rats. Neurol Sci. 2013; 34(7): 1117-24.

19. Odacı E, İkinci A, Yıldırım M, Kaya H, Akça M, Hanc1 H, et al. The effects of 900 megahertz electromagnetic field applied in the prenatal period on spinal cord morphology and motor behavior in female rat pups. Neuroquantology. 2013; 4:573-81.

20. Sokolovic D, Djordjevic B, Kocic G, Babovic P, Ristic G, Stanojkovic Z, et al. The effect of melatonin on body mass and behaviour of rats during an exposure to microwave radiation from mobile phone. Bratisl Lek Listy. 2012; 113(5): 265-9.

21. Kumlin $\mathrm{T}$, Iivonen $\mathrm{H}$, Miettinen $\mathrm{P}$, Juvonen $\mathrm{A}$, van Groen T, Puranen L, et al. Mobile phone radiation and the developing brain: behavioral and morphological effects in juvenile rats. Radiat Res. 2007; 168(4): 4719.

22. Khirazova EE, Baizhumanov AA, Trofimova LK, Deev LI, Maslova MV, Sokolova NA, et al. Effects of GSM-frequency electromagnetic radiation on some physiological and biochemical parameters in rats. Bull Exp Biol Med. 2012; 153(6): 817-20.

23. Nittby H, Grafström G, Tian DP, Malmgren L, Brun A, Persson BR, et al. Cognitive impairment in rats after long-term exposure to GSM-900 mobile phone radiation. Bioelectromagnetics. 2008; 29(3): 219-32.

24. Ahmadi R, Khakpour B, Parsania S. The effects of mobile phone radiation on serum level of cortisol and anxiety in male rats. Armaghane Danesh. 2015; 20 (7): 585-600.

25. Zhang JP, Zhang KY, Guo L, Che QL, Gao P, Wang $\mathrm{T}$, et al. Effects of $1.8 \mathrm{GHz}$ radiofrequency fields on the emotional behavior and spatial memory of adolescent mice. Int J Environ Res Public Health. 2017; 14(11): 1344.

26. Junior LC, Guimaraes Eda S, Musso CM, Stabler CT, Garcia RM, Mourao-Junior CA, et al. Behavior and memory evaluation of Wistar rats exposed to $1 \cdot 8 \mathrm{GHz}$ radiofrequency electromagnetic radiation. Neurol Res. 2014; 36(9): 800-3.

27. Shehu A, Mohammed A, Magaji RA, Muhammad MS. Exposure to mobile phone electromagnetic field radiation, ringtone and vibration affects anxiety-like behaviour and oxidative stress biomarkers in albino wistar rats. Metab Brain Dis. 2016; 31(2): 355-62.

28. Jadidi M, Miladi-Gorji H, Mahdinezhad M, Torkmandi H. Effects of mobile phone jammer on the anxiety level of male and female mice. Physiol Pharmacol. 2014; 18 (3): 354-63.

29. Kumar RS, Sareesh NN, Nayak S, Mailankot M. Hypoactivity of Wistar rats exposed to mobile phone on elevated plus maze. Indian J Physiol Pharmacol. 2009; 53(3): 283-6.

30. Aldad TS, Gan G, Gao XB, Taylor HS. Fetal radiofrequency radiation exposure from 800-1900 MHz-rated cellular telephones affects neurodevelopment and behavior in mice. Sci Rep. 2012; 2: 312.

31. Esmaili MH, Masoumi H, Jadidi M, Miladi-Gorji H, Nazari H. The effects of acute mobile phone radiation on the anxiety level of male rats. Middle East $\mathrm{J}$ Rehabil Health Stud. 2017; 4(2): e43478.

32. Gupta SK, Patel SK, Tomar MS, Singh SK, Mesharam MK, Krishnamurthy S. Long-term exposure of $2450 \mathrm{MHz}$ electromagnetic radiation induces stress and anxiety like behavior in rats. Neurochem Int. 2019; 128: 1-13.

33. Sharma A Sharma S, Shrivastava S, Kumar Singhal P, Shukla S. Mobile phone induced cognitive and neurochemical consequences. J Chem Neuroanat. 2019; 102: 101684.

34. Othman H, Ammari M, Sakly M, Abdelmelek H. Effects of prenatal exposure to WiFi signal (2.45 $\mathrm{GHz}$ ) on postnatal development and behavior in rat: Influence of maternal restraint. Behav Brain Res. 2017a; 326: 291-302.

35. Othman H, Ammari M, Rtibi K, Bensaid N, Sakly M, Abdelmelek H. Postnatal development and behavior 
effects of in-utero exposure of rats to radiofrequency waves emitted from conventional WiFi devices. Environ Toxicol Pharmacol. 2017b; 52: 239-47.

36. Othman H, Ammari M, Sakly M, Abdelmelek H. Effects of repeated restraint stress and WiFi signal exposure on behavior and oxidative stress in rats. Metab Brain Dis. 2017c; 32(5): 1459-69.

37. Kumar M, Singh SP, Chaturvedi CM. Chronic nonmodulated microwave radiations in mice produce anxiety-like and depression like behaviours and calcium- and NO-related biochemical changes in the brain. Exp Neurobiol. 2016; 25(6): 318-27.

38. Cosquer B, Galani R, Kuster N, Cassel JC. Wholebody exposure to $2.45 \mathrm{GHz}$ electromagnetic fields does not alter anxiety responses in rats: a plus-maze study including test validation. Behav Brain Res. 2005; 156(1): 65-74.

39. Obajuluwa AO, Akinyemi AJ, Afolabi OB, Adekoya $\mathrm{K}$, Sanya JO, Ishola AO. Exposure to radio-frequency electromagnetic waves alters acetylcholinesterase gene expression, exploratory and motor coordinationlinked behaviour in male rats. Toxicol rep. 2017; 4: 530-4.

40. Zhang Y, Li Z, Gao Y, Zhang C. Effects of fetal microwave radiation exposure on offspring behavior in mice. J Radiat Res. 2015; 56(2): 261-8. 